\title{
Graphene-Modified Composites and Electrodes and Their Potential Applications in the Electro-Fenton Process
}

\author{
Tian Yu and Carmel B. Breslin * \\ Department of Chemistry, Maynooth University, Maynooth, Co. Kildare, Ireland; Tian.Yu.2020@mumail.ie \\ * Correspondence: Carmel.Breslin@mu.ie
}

Received: 25 April 2020; Accepted: 11 May 2020; Published: 14 May 2020

check for updates

\begin{abstract}
In recent years, graphene-based materials have been identified as an emerging and promising new material in electro-Fenton, with the potential to form highly efficient metal-free catalysts that can be employed in the removal of contaminants from water, conserving precious water resources. In this review, the recent applications of graphene-based materials in electro-Fenton are described and discussed. Initially, homogenous and heterogenous electro-Fenton methods are briefly introduced, highlighting the importance of the generation of $\mathrm{H}_{2} \mathrm{O}_{2}$ from the two-electron reduction of dissolved oxygen and its catalysed decomposition to produce reactive and oxidising hydroxy radicals. Next, the promising applications of graphene-based electrodes in promoting this two-electron oxygen reduction reaction are considered and this is followed by an account of the various graphene-based materials that have been used successfully to give highly efficient graphene-based cathodes in electro-Fenton. In particular, graphene-based composites that have been combined with other carbonaceous materials, doped with nitrogen, formed as highly porous aerogels, three-dimensional materials and porous gas diffusion electrodes, used as supports for iron oxides and functionalised with ferrocene and employed in the more effective heterogeneous electro-Fenton, are all reviewed. It is perfectly clear that graphene-based materials have the potential to degrade and mineralise dyes, pharmaceutical compounds, antibiotics, phenolic compounds and show tremendous potential in electro-Fenton and other advanced oxidation processes.
\end{abstract}

Keywords: electro-Fenton; graphene; oxygen reduction reaction; advanced oxidation; hydrogen peroxide

\section{Introduction}

As the quality of water continues to decrease, there has been an ever-increasing interest in advanced oxidation processes (AOPs) that are capable of mineralising organic pollutants to $\mathrm{CO}_{2}, \mathrm{H}_{2} \mathrm{O}$ and inorganic ions, or at least to harmless products [1]. These organic pollutants, which include pesticides, herbicides, dye molecules, phenolic compounds, antibiotics, pharmaceuticals and surfactants, are normally very difficult to degrade [2,3]. Conventional water treatment plants are not always capable of removing these emerging contaminants. Although they are present in water at relatively low concentrations, their presence and ability to produce even more harmful metabolites have led to the development of AOPs. These processes range from UV irradiation and ozonation to electrochemical oxidation $[1,4,5]$. The electro-Fenton (E-Fenton) process has been identified as a particularly attractive technology, as it is clean and can be used to generate reasonably high concentrations of hydroxy radicals, $\mathrm{OH}^{\bullet}$, that can be employed in the oxidation, degradation and mineralisation of various organic compounds and is considered to be one of the more promising and emerging AOPs [1,6,7].

The main principle of the E-Fenton process is summarised in Equation (1), where the oxidation of $\mathrm{Fe}^{2+}$ to $\mathrm{Fe}^{3+}$ facilitates the conversion of $\mathrm{H}_{2} \mathrm{O}_{2}$ to the highly oxidising $\mathrm{OH}^{\bullet}$, with a standard reduction 
potential of $2.56 \mathrm{~V}$ vs. SCE (saturated calomel electrode). Consequently, these $\mathrm{OH}^{\bullet}$ radicals can be employed to mineralise a large number of organic contaminants. The sustained production of $\mathrm{OH}^{\bullet}$ requires both $\mathrm{Fe}^{2+}$ and $\mathrm{H}_{2} \mathrm{O}_{2}$. The $\mathrm{Fe}^{2+}$ ions can be regenerated through the reduction of $\mathrm{Fe}^{3+}$ at the cathode (Equation (2)), provided the $\mathrm{Fe}^{3+}$ ions do not form hydroxide precipitates in the solution phase, to give a near-continuous supply of $\mathrm{Fe}^{2+}$. The $\mathrm{H}_{2} \mathrm{O}_{2}$ is produced by the two-electron reduction of dissolved oxygen; see Equation (3).

$$
\begin{gathered}
\mathrm{Fe}^{2+}+\mathrm{H}_{2} \mathrm{O}_{2}+\mathrm{H}^{+} \rightarrow \mathrm{Fe}^{3+}+\mathrm{OH}^{\bullet}+\mathrm{H}_{2} \mathrm{O} \\
\mathrm{Fe}^{3+}+\mathrm{e}^{-} \rightarrow \mathrm{Fe}^{2+} \\
\mathrm{O}_{2}+2 \mathrm{H}^{+}+2 \mathrm{e}^{-} \rightarrow \mathrm{H}_{2} \mathrm{O}_{2}
\end{gathered}
$$

However, the classical homogeneous E-Fenton process suffers from a number of limitations. The generation of secondary sludge, as ferric and ferrous ions in the treated wastewater, gives hydroxide precipitates and these must be removed, adding cost and reducing the overall efficiency. To limit the formation of solid $\mathrm{Fe}(\mathrm{OH})_{2}$ and $\mathrm{Fe}(\mathrm{OH})_{3}$, the system must be operated under stringent $\mathrm{pH}$ control as these hydroxide species are only soluble at $\mathrm{pH}$ values lower than about 4.0. Therefore, the $\mathrm{pH}$ of water samples or effluents must be acidified and brought to an acidic $\mathrm{pH}$ value of approximately 2.0 to 3.0. Moreover, the $\mathrm{OH}^{\bullet}$ radicals are not continuously generated and require a supply of pure oxygen.

In more recent years, heterogeneous E-Fenton has emerged as a solution to the issues with iron hydroxide precipitation [8-10]. In this case, iron catalysts are incorporated as solids, usually oxides, such as $\mathrm{Fe}_{3} \mathrm{O}_{4}$, into a suitable electrode material. In Figure 1, a schematic is provided, illustrating homogenous and heterogeneous E-Fenton. As shown in Figure 1 a for homogeneous E-Fenton, $\mathrm{Fe}^{2+}$ is generated from a sacrificial anode and reacts with the $\mathrm{H}_{2} \mathrm{O}_{2}$ in the bulk solution. An iron salt can also be added to the cell to facilitate this reaction. In contrast, the aim in heterogeneous E-Fenton (Figure 1b) is to maintain the $\mathrm{Fe}^{2+} / \mathrm{Fe}^{3+}$ couple in the solid state [11] and, provided the cathode promotes the two-electron reduction reaction to give $\mathrm{H}_{2} \mathrm{O}_{2}$, these coupled reactions can be sustained.

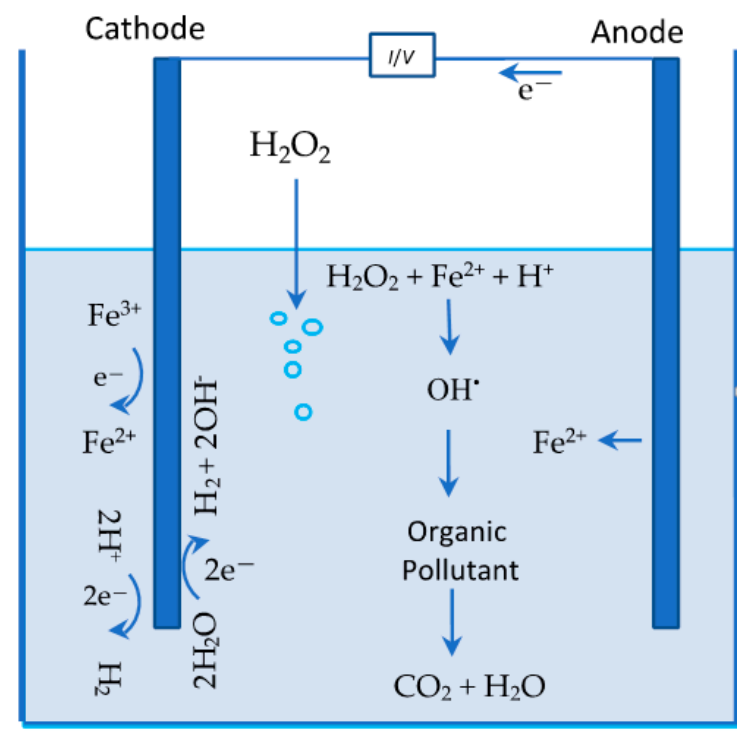

(a)

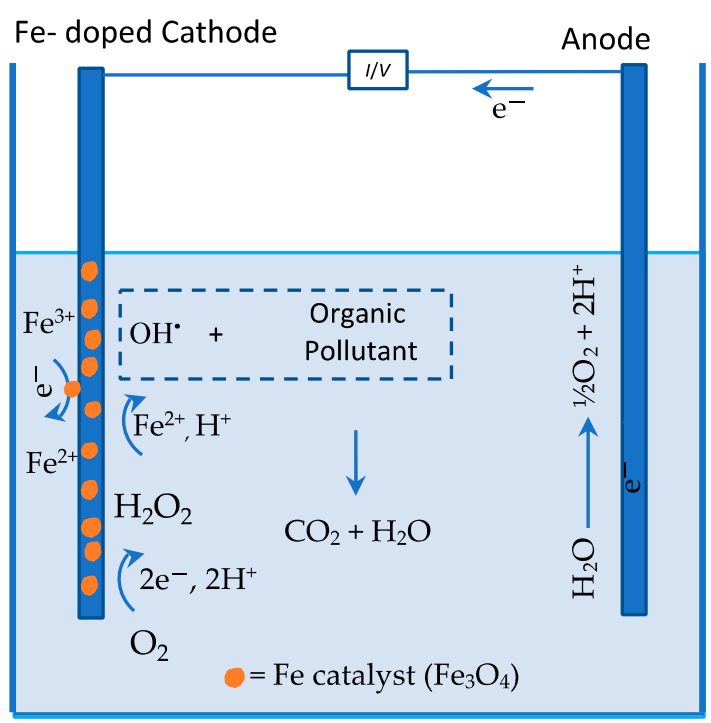

(b)

Figure 1. Schematic of (a) homogeneous and (b) heterogeneous electro-Fenton (E-Fenton).

Although heterogeneous E-Fenton can be employed over a wide $\mathrm{pH}$ range, issues still remain with the sluggish reduction of $\mathrm{Fe}^{3+}$ to $\mathrm{Fe}^{2+}$ within the iron-containing catalysts and long-term instability of the catalysts. Furthermore, high and sustainable amounts of $\mathrm{H}_{2} \mathrm{O}_{2}$ are required to provide efficient 
levels of $\mathrm{OH}^{\bullet}$ and this can be difficult as the two-electron oxygen reduction reaction is often complicated by the competing four-electron transfer reaction. Therefore, it is no surprise that considerable effort has been devoted to the design and production of cathode materials that facilitate the formation of high yields of $\mathrm{H}_{2} \mathrm{O}_{2}$. Metals such as $\mathrm{Au}, \mathrm{Pt}, \mathrm{Pd}$ and $\mathrm{Ru}[12,13]$ are effective catalysts for the production of $\mathrm{H}_{2} \mathrm{O}_{2}$, with relatively low overpotentials and very good conductivity. However, these are not cost-effective. Recently, carbon-based electrodes and, in particular, graphene-based materials are beginning to be employed in E-Fenton cells and in E-Fenton technologies. This developing interest in the use of graphene-based materials in E-Fenton can be seen clearly in Figure 2, where the number of publications is shown as a function of the year of publication for Fenton, which covers the classical Fenton reagents, E-Fenton, and graphene-based materials coupled with E-Fenton. The publications assigned to Fenton include E-Fenton and this comparison highlights the rise in the popularity of E-Fenton over recent years. It is also very evident from this analysis that graphene-based materials are being increasingly considered as electrodes in E-Fenton cells and are likely to make a more significant impact in the near future.

In this review, graphene-modified electrodes and composites and their applications in E-Fenton are reviewed and discussed. There are a number of review papers devoted to AOPs and E-Fenton technologies [14-17], for example, Brillas and Martinez-Huitle [15] have reviewed various electrochemical treatments, including $\mathrm{OH}^{\bullet}$ radicals as oxidants; Nidheesh et al. [18] have reviewed various electrochemical advanced oxidation processes for the removal of dye molecules, while Bechelany and co-workers [19] have considered a number of carbonaceous materials for energy and environmental applications, such as E-Fenton. Likewise, there are some excellent reviews published on graphene/rGO and its applications [20,21]. Nag et al. [20] have described the applications of graphene/rGO in sensors, Chang et al. [21] have reviewed the use of graphene-based materials as anodes in batteries, while the applications of graphene-based composites to electrocatalysis [22], energy storage [23] and flexible electronics [24] have all been described and reviewed. However, to the best of our knowledge, there is only one mini-review that considers graphene-based cathodes in E-Fenton [25]. In this present review, we consider a more extensive variety of graphene-based composites and electrodes and discuss their emerging applications in E-Fenton. The methods employed in forming these composites and their subsequent performance in catalysing the selective two-electron oxygen reduction reaction and the removal of a number of micropollutants and organic contaminants in E-Fenton are reviewed and discussed.

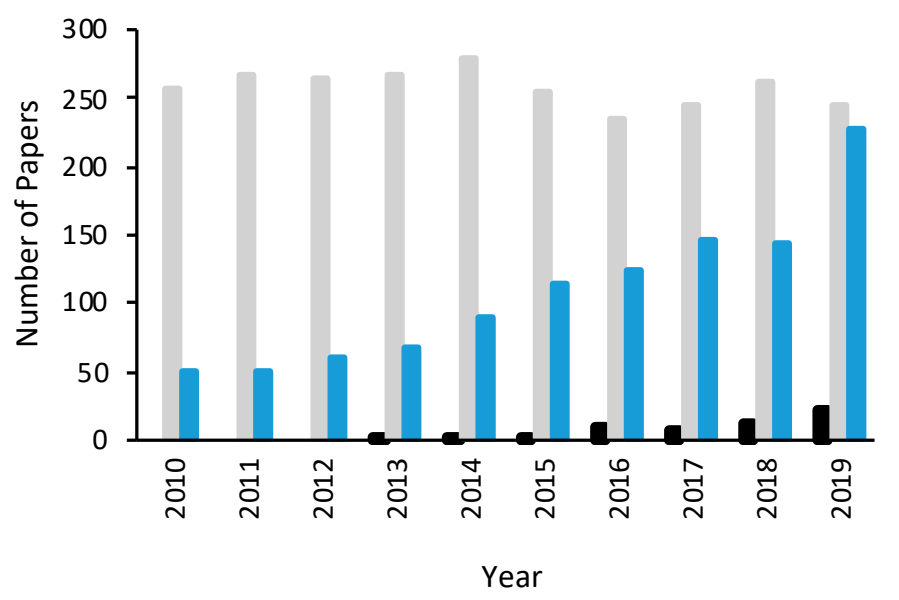

Figure 2. Number of publications shown as a function of the year of publication, taken from Scopus, for Fenton (grey), E-Fenton (blue) and E-Fenton coupled with graphene-based materials (black).

\section{Oxygen Reduction Reaction and Graphene-Based Electrodes}

The oxygen reduction reaction is important in several applications [26,27] and occurs by two different pathways, depending on the solution $\mathrm{pH}$ and cathode material. The two-electron reduction 
reaction is illustrated in Equation (3), while the competing four-electron reduction is given in Equation (4).

$$
\mathrm{O}_{2}+4 \mathrm{H}^{+}+4 \mathrm{e}^{-} \rightarrow 2 \mathrm{H}_{2} \mathrm{O}
$$

As high yields of $\mathrm{H}_{2} \mathrm{O}_{2}$ are needed to provide the essential $\mathrm{OH}^{\bullet}$ species, the two-electron reduction reaction is the preferred reaction in the E-Fenton cell and therefore new catalysts are required to give high selectivity for the two-electron over the four-electron oxygen reduction reaction. Not only is this reaction highly relevant to E-Fenton, but $\mathrm{H}_{2} \mathrm{O}_{2}$ is used in a number of other applications and it is currently formed using an energy-demanding anthraquinone oxidation process [28]. Consequently, it is no surprise that, in the past decade, considerable attention has been devoted to designing new materials that can be employed to generate $\mathrm{H}_{2} \mathrm{O}_{2}$ through the two-electron reduction of dissolved oxygen $[29,30]$. Despite this considerable interest, the origin of the selectivity is still poorly understood. The four-electron transfer reaction is favoured by thermodynamics, which may indicate that selectivity for the two-electron transfer reaction originates in kinetics [31]. In addition to selectivity issues, there are a number of parasitic reactions that can occur at the cathode or in the bulk solution [29]. The reduction of $\mathrm{H}_{2} \mathrm{O}_{2}$ to $\mathrm{H}_{2} \mathrm{O}$ may take place at the cathode-solution interface [32] (Equation (5)), or it may give $\mathrm{O}_{2}$ and $\mathrm{H}_{2} \mathrm{O}$ through a disproportionation reaction [33] (Equation (6)), or be oxidised at the anode in the cell, or through the generation of the $\mathrm{HO}_{2}$ intermediate (Equation (7)) [34]. It is generally accepted that the highest yield of $\mathrm{H}_{2} \mathrm{O}_{2}$ is achieved at $\mathrm{pH}$ values between 2.0 and 3.0 [35], with more acidic conditions favouring the reduction of $\mathrm{H}^{+}$, while the lack of protons with increasing $\mathrm{pH}$ reduces the rate of the reaction.

$$
\begin{gathered}
\mathrm{H}_{2} \mathrm{O}_{2}+2 \mathrm{e}^{-}+2 \mathrm{H}^{+} \rightarrow 2 \mathrm{H}_{2} \mathrm{O} \\
\mathrm{H}_{2} \mathrm{O}_{2} \rightarrow \mathrm{O}_{2}+2 \mathrm{H}_{2} \mathrm{O} \\
\mathrm{H}_{2} \mathrm{O}_{2} \rightarrow \mathrm{HO}_{2}+\mathrm{H}^{+}+\mathrm{e}^{-} \rightarrow \mathrm{O}_{2}+2 \mathrm{H}^{+}+2 \mathrm{e}^{-}
\end{gathered}
$$

In an attempt to overcome these complex issues, various carbon-based materials have been considered, as these are generally cost effective and facilitate the two-electron reduction of oxygen. In particular, carbon in different forms, such as amorphous carbon, glassy carbon, graphite, fullerenes and carbon nanotubes have all been evaluated [29]. However, research is increasingly focused on the graphene family, as it presents a genuine alternative, with high surface area, moderate to good conductivity, excellent stability and its properties can be tailored using heteroatom doping and it can be easily combined with other materials [36-39]. For example, Yang et al. [40] employed a graphite felt electrode modified with electrochemically generated exfoliated graphene and carbon black and reported a $\mathrm{H}_{2} \mathrm{O}_{2}$ production rate of $7.7 \mathrm{mg} \mathrm{h}^{-1} \mathrm{~cm}^{-2}$.

Graphene is a two-dimensional material with $s p^{2}$-hybridised carbon atoms arranged in a two-dimensional honeycomb monolayer to produce a one-atom-thick sheet. Graphene can be produced using a variety of both top-down and bottom-up approaches, including exfoliation, sonication, ball milling, chemical vapour deposition and epitaxial growth [41]. However, the production of pristine graphene with minimum defects is still challenging and while mechanical cleavage of graphite results in high quality graphene flakes, the yield is low, making the mass production of graphene demanding and time consuming [41]. One of the more common routes for the production of graphene-based materials is the formation of graphene oxide (GO) followed by its reduction to reduced $\mathrm{GO}(\mathrm{rGO})$ [42-44]. GO is typically synthesised by oxidising graphite in a mixture of $\mathrm{NaNO}_{3}, \mathrm{KMnO}_{4}$ and $\mathrm{H}_{2} \mathrm{SO}_{4}$, which is widely known as the modified Hummers method [42-46]. Once the graphite is oxidised, the interlayer spacing increases and the resulting expanded interlayer, combined with ultrasonication, allows for liquid-phase exfoliation in order to produce the GO sheets.

This oxidation process introduces a number of negatively charged oxygen-containing groups, such as hydroxy and carboxy groups, to the GO sheets and as a result, the GO sheets have good hydrophilic properties. GO exhibits good stability as a colloidal solution and this is very useful for solution processing approaches. The GO sheets can be subsequently reduced to give rGO, which 
has a much higher conductivity, and it is this member of the graphene family that is most suitable for electrochemical applications, such as the reduction of dissolved oxygen to produce $\mathrm{H}_{2} \mathrm{O}_{2}$ in E-Fenton applications. The reduction methods employed are generally thermal or chemical reduction processes [47]. The thermal reduction involves heating the GO to temperatures in the vicinity of 400 to $1100{ }^{\circ} \mathrm{C}$, where most of the oxygen-containing groups are transformed to gaseous $\mathrm{CO}$ or $\mathrm{CO}_{2}$, giving a reduction of GO and the formation of rGO. Various reducing agents, such as borohydride, hydrazine or hydrogen iodide can be employed at room temperature or with mild heating to give rGO. However, some of these chemicals have environmental concerns and they can introduce impurities to the carbon matrix. These health and environmental issues can be overcome by using ascorbic acid as the reducing agent. This has been successfully employed to reduce GO and the resulting rGO was shown to have good conductivity [48]. The electrochemical reduction of GO is another very effective and simple route to obtain rGO [49-51]. For example, Guo et al. [50] used a potential of $-1.5 \mathrm{~V}$ to reduce GO, giving a green and fast process with no evidence of contamination of the rGO sheets. However, the rGO produced from all these approaches contains some oxygen-containing functional groups.

Different approaches have been used in forming graphene-based cathodes in an attempt to give enhanced and selective production of $\mathrm{H}_{2} \mathrm{O}_{2}$. These approaches include various electrophoretic and electrodeposition routines to generate graphene-based cathodes, graphene-based materials deposited from slurries or suspensions at graphite or carbon felt electrodes which act as supports, graphene-based inks, porous graphene-based aerogels, three-dimensional graphene-modified electrodes, heteroatom doped graphene composites, graphene composites combined with iron oxides and graphene-based diffusion electrodes. These are now described and discussed in the following sections.

\subsection{Graphene Modified Carbon/Graphite Felt Electrodes and Other Supports}

One of the most common approaches is to use carbon or graphite felt as a support for GO or rGO as these three-dimensional felt cathodes have low cost, high surface area, excellent conductivity and high porosity. The exfoliated GO/rGO can be deposited at the carbon or graphite electrodes using electrophoretic deposition [52], coated from a liquid solution phase with different additives, such as polytetrafluoretyhylene (PTFE) and carbon black to form a slurry, followed by a heating or an annealing process of the electrode $[39,53,54]$. Various additives have been employed in formulating these graphene-containing suspensions or slurries. In several papers polytetrafluroethylene (PTFE), a synthetic fluropolymer with good adhesion and lubricating properties, has been used successfully $[55,56]$. Spin coating has also been employed to deposit GO from slurries [57], while in some cases, the treated carbon or graphite felt is immersed in the rGO containing suspension or slurry [4], or dip-coated [58,59]. The solution or slurry coating approaches enable the addition of various additives that have the potential to enhance the removal of micropollutants using E-Fenton. However, the addition of binders, such as PTFE, can reduce the electric conductivity and increase the impedance of the final composite [60], while hindering ion permeability at the electrode-solution interface [61]. The electrophoretic deposition routines can be easily coupled with the electrochemical reduction of $\mathrm{GO}$ to form $\mathrm{rGO}$ without the need for reducing agents and binders that are toxic in many cases. Interestingly, in a comparison of the reduction of GO to rGO using a constant potential reduction, chemical reduction and thermal reduction, it was concluded that the electrochemical reduction was the best option, in terms of simplicity, cost, ecology and performance in the mineralisation of an azo dye [62].

Indeed, these electrochemical approaches, employing combinations of electrochemical exfoliation and electrophoretic deposition, followed by the reduction of GO to rGO, have been used to coat carbon felt electrodes [52], while in some cases the electrochemically exfoliated GO is combined with carbon black before being deposited at the felt electrodes $[3,40]$. These graphene-modified electrodes have been shown to faciliate the oxygen reduction reaction, producing $\mathrm{H}_{2} \mathrm{O}_{2}$ with low energy consumptions of $9.7 \mathrm{kWh} \mathrm{kg}^{-1}$ [39] and $3.08 \mathrm{kWh} \mathrm{kg}^{-1}$ [3] and have been employed successfully to remove acid orange [52], sulfadiazine [3] and imatinib [55]. 
On the other hand, graphene-containing slurries can be readily formed using exfoliated or electrochemically exfoliated GO and these have been combined with quinones (AQ), which have the ability to generate $\mathrm{H}_{2} \mathrm{O}_{2}$ (Equations (8) and (9)). For example, Gao et al. [53] used GO, PTFE and anthraquinone sulfonate to modify carbon felt to fabricate a hybrid electrode. The catalytic oxygen reduction reaction was greatly enhanced in the presence of the quinone, resulting in the efficient removal of Rhodamine B. The authors proposed a mechanism whereby a semi-quinone (s-Q) anion radical is formed at the cathode (Equation (10)). This is followed by a catalysed reduction of dissolved oxygen to generate the oxygen radical anion (Equation (11)), which then combines with protons to generate $\mathrm{H}_{2} \mathrm{O}_{2}$; see Equation (12).

$$
\begin{gathered}
\mathrm{AQ}+2 \mathrm{H}^{+}+2 \mathrm{e}^{-} \rightarrow \mathrm{AQH}_{2} \quad E^{0}=0.43 \mathrm{~V} \text { vs. SCE } \\
\mathrm{AQH}+\mathrm{O}_{2} \rightarrow \mathrm{AQ}+\mathrm{H}_{2} \mathrm{O}_{2} \\
\mathrm{AQ}+\mathrm{e}^{-} \rightarrow \mathrm{s}^{\bullet--} \\
\mathrm{O}_{2}+\mathrm{s}^{-\mathrm{Q}^{--}} \rightarrow \mathrm{O}_{2}^{\bullet-}+s-\mathrm{Q} \\
2 \mathrm{O}_{2}^{\bullet-}+2 \mathrm{H}^{+} \rightarrow \mathrm{H}_{2} \mathrm{O}_{2}+\mathrm{O}_{2}
\end{gathered}
$$

It is well established that a number of oxygen-containing functional groups, such as epoxides $(\mathrm{C}-\mathrm{O}-\mathrm{C})$, hydroxy $(\mathrm{OH})$, carboxylic $(\mathrm{COOH})$ and carbonyl groups $(\mathrm{C}=\mathrm{O})$ are present on $\mathrm{GO}$ nanosheets [63]. However, other oxygen-containing groups, such as ketones and quinones have been detected. Aliyev et al. [64], using a combination of surface analytical techniques, clearly identified quinone groups on GO layers, and these may also contribute to the generation of $\mathrm{H}_{2} \mathrm{O}_{2}$ when $\mathrm{GO} / \mathrm{rGO}$ is employed as the cathode material. Indeed, Nambi and co-workers [65] attributed some of the enhanced production of $\mathrm{H}_{2} \mathrm{O}_{2}$ and the degradation efficiency of E-Fenton to quinone functional groups on electrochemically exfoliated rGO.

Graphene oxide can be easily functionalised with ferrocene [66,67], and ferrocene-functionalised rGO has been deposited at graphite felt electrodes. For example, Nambi and co-workers [58] designed a cathode by fabricating ferrocene-functionalised rGO on graphite felt electrodes and studied its heterogeneous E-Fenton reaction for the degradation of ciprofloxacin at neutral $\mathrm{pH}$ conditions. The removal rate of ciprofloxacin was computed as $0.035 \mathrm{~min}^{-1}$ for the ferrocene-modified rGO electrode, significantly higher than the value of $0.004 \mathrm{~min}^{-1}$ obtained for the unmodified graphite felt and also higher than $0.010 \mathrm{~min}^{-1}$, which was the rate constant observed with the reduced rGO-modified felt electrode. The authors concluded that the rGO and ferrocene participated in sequential steps, with $\mathrm{rGO}$ facilitating the production of $\mathrm{H}_{2} \mathrm{O}_{2}$, while the $\mathrm{Fe}^{2+}$ centre in ferrocene catalysed the decomposition of $\mathrm{H}_{2} \mathrm{O}_{2}$ to form $\mathrm{OH}^{\bullet}$ and $\mathrm{Fe}^{3+}$-centred ferricenium. The same group studied the ferrocene-functionalised rGO felt electrode as an E-Fenton catalyst using rotating disc voltammetry for the removal of ciprofloxacin and carbamazepine [59]. Using rotating disc voltammetry, which gives improved mass transfer, a continuous supply of reactive oxygen species was achieved without aeration of the solution, to give $\mathrm{OH}^{\bullet}$ concentrations of $644 \mu \mathrm{M}, 264 \mu \mathrm{M}$ and $163 \mu \mathrm{M}$ at pH values of 3.0, 7.0 and 9.0, respectively, facilitating the removal of contaminants over a wide $\mathrm{pH}$ range.

Using another approach, Mi et al. [4] combined rGO with $\mathrm{WO}_{3}$ and $\mathrm{Ce}$ and deposited the hybrid composite, $\mathrm{rGO} / \mathrm{Ce} / \mathrm{WO}_{3}$, on carbon felt. This composite was employed in E-Fenton to remove ciprofloxacin with complete degradation within $1 \mathrm{~h}$, and a mineralisation degree of $98.55 \%$ within $8 \mathrm{~h}$. It was suggested that the $\mathrm{Ce}^{3+}$ catalysed the decomposition of $\mathrm{H}_{2} \mathrm{O}_{2}$ to give the $\mathrm{OH}^{\bullet}$ radical species (Equation (13)), while superoxide was generated from the reaction between $\mathrm{Ce}^{3+}$ and dissolved $\mathrm{O}_{2}$ (Equation (14)) and between $\mathrm{W}^{5+}$ and $\mathrm{O}_{2}$ (Equation (15)). The $\mathrm{Ce}^{4+}$ was recycled to $\mathrm{Ce}^{3+}$ through a simple reduction step (Equation (16)), while $\mathrm{Fe}^{2+}$ ions added to the E-Fenton cell also facilitated the reduction of $\mathrm{Ce}^{4+}$ (Equation (17)).

$$
\mathrm{Ce}^{3+}+\mathrm{H}_{2} \mathrm{O}_{2}+\mathrm{H}^{+} \rightarrow \mathrm{Ce}^{4+}+\mathrm{OH}^{\bullet}+\mathrm{H}_{2} \mathrm{O}
$$




$$
\begin{gathered}
\mathrm{Ce}^{3+}+\mathrm{O}_{2} \rightarrow \mathrm{Ce}^{4+}+\mathrm{O}_{2}^{-\bullet} \\
\mathrm{W}^{5+}+\mathrm{O}_{2} \rightarrow \mathrm{W}^{6+}+\mathrm{O}_{2}{ }^{-\bullet} \\
\mathrm{Ce}^{4+}+\mathrm{e}^{-} \rightarrow \mathrm{Ce}^{3+} \\
\mathrm{Ce}^{4+}+\mathrm{Fe}^{2+} \rightarrow \mathrm{Ce}^{3+}+\mathrm{Fe}^{3+}
\end{gathered}
$$

Graphene/GO has also been combined with conducting polymers and used in E-Fenton. In a recent study, a simple electropolymerisation method was employed to deposit poly $(3,4-$ ethylenedioxythiophene) (PEDOT), sodium polystyrene sulfonate (NaPSS) and GO on graphite felt electrodes [68]. This GO/PEDOT:NaPSS showed much greater rates of $\mathrm{H}_{2} \mathrm{O}_{2}$ production and greater efficiency in the degradation of methylene blue in heterogeneous E-Fenton compared with the GO-free PEDOT:NaPSS. This was attributed to a synergistic effect between PEDOT and GO, promoting higher electron transfer rates.

In addition to electrophoretic deposition and coating from graphene-containing slurries, there has been considerable interest in graphene-based inks that can be painted or printed onto substrates $[69,70]$. This approach has been employed to produce graphene-based cathodes in E-Fenton [6,71]. Conducting graphene-based inks have been formed in ethanol and water mixtures using Nafion as a binder and dispersant, and the resulting ink coated onto carbon cloth [71] and carbon fibres [6]. These ink-coated cathodes have been shown to give rise to a near doubling of the amount of $\mathrm{H}_{2} \mathrm{O}_{2}$ generated and a three-fold increase in the rate of phenol degradation. A graphene-based paste cathode has also been employed to degrade a pharmaceutical product [72]. The paste was formed by mixing rGO with graphite powder and paraffin, which served as the binding agent. Divyapriya et al. [73] used another approach, whereby a liquid crystal display glass was utilised as a supporting matrix for the deposition of a thin graphene-modified electrode without the need for binders or linkers. GO was drop casted on the glass and electrochemically reduced to rGO and then used for the oxidation and degradation of ciprofloxacin. The authors showed that the drop cast electrode exhibited good stability. Graphene oxide has also been deposited on stainless steel to create a membrane for the removal of paracetamol [74], and an electrode to oxidise and remove arsenic [5], while a PTFE membrane was modified with graphene and used as a catalytic membrane to both concentrate and oxidise an antibiotic [75].

In most of these approaches, the graphene-modified electrode is compared to the conducting carbon or graphite felt or carbon cloth substrate electrodes and the addition of rGO clearly enhances the rate of $\mathrm{H}_{2} \mathrm{O}_{2}$ generation to give a more efficient removal of the contaminants. Interestingly, it was shown by Wang et al. [57], who employed polyvinylidene difluoride to fabricate both carbon nanotube (CNT) modified felt and graphene-modified felt electrodes, that the graphene-modified carbon felt was superior in the degradation of an azo dye molecule, reaching degradation rates of $70.1 \%$, compared to the lower rates of $55.3 \%$ evident with the CNT-modified electrode. While both modifications enhanced the azo dye degradation rate compared to the untreated carbon felt electrode, the graphene-modified electrode produced a higher quantity of $\mathrm{H}_{2} \mathrm{O}_{2}$. This suggests that the graphene-modified electrodes are not only more superior than the conducing graphite or carbon substrates used in their fabrication, but they may also be more efficient in producing $\mathrm{H}_{2} \mathrm{O}_{2}$ than carbon nanotubes. The impressive performance of the graphene-modified carbon/graphite felt electrodes is clearly illustrated in Table 1 . For comparative purposes, some very recently optimised and high-performing graphite-based electrodes are included. Although the amount of $\mathrm{H}_{2} \mathrm{O}_{2}$ generated is expressed differently, sometimes as rates and in other cases as mass per volume, it is evident that a graphene-based system can be employed to give the more efficient generation of $\mathrm{H}_{2} \mathrm{O}_{2}$ with relatively high rate constants for the removal of a variety of contaminants.

\subsection{Porous Graphene Electrodes}

Porous graphene-based composites that can be employed as aerogels, foams and as gas diffusion electrodes are interesting and these new materials are beginning to emerge in E-Fenton. 
Table 1. Summary of graphene-based felt electrodes in generating $\mathrm{H}_{2} \mathrm{O}_{2}$ or $\mathrm{OH}^{\bullet}$ and in the removal of contaminants.

\begin{tabular}{|c|c|c|c|c|c|}
\hline System & Pollutant & Experimental Conditions & $k / \min ^{-1}$ & $\mathrm{H}_{2} \mathrm{O}_{2} / \mathrm{OH}^{\bullet}$ & Ref. \\
\hline $\begin{array}{l}\text { Ferrocene- } \\
\text { rGO/graphite }\end{array}$ & $\begin{array}{l}\text { Cipro- } \\
\text { Floxacin }\end{array}$ & $\begin{array}{c}\mathrm{V}=150 \mathrm{~mL}, \mathrm{E}=-1.5 \mathrm{~V} \\
\mathrm{~A}=10 \mathrm{~cm}^{2}, \mathrm{t}=30 \mathrm{~min}, \text { air } \\
\text { sparging }\end{array}$ & $\begin{array}{c}0.035 \text { (acidic) } \\
0.222 \text { (neutral) }\end{array}$ & $\begin{array}{c}\mathrm{OH}^{\bullet}: \\
426 \mu \mathrm{M} \text { (acidic) } \\
247 \mu \mathrm{M} \text { (neutral) }\end{array}$ & [58] \\
\hline rGO-LCD & $\begin{array}{l}\text { Cipro- } \\
\text { Floxacin }\end{array}$ & 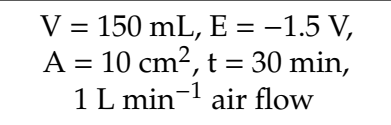 & $\begin{array}{c}0.019 \text { (neutral) } \\
0.034 \text { (acidic) }\end{array}$ & $\begin{array}{c}\mathrm{H}_{2} \mathrm{O}_{2}: \\
45 \mathrm{mg} \mathrm{L}^{-1} \text { (acidic) } \\
20 \mathrm{mg} \mathrm{L}^{-1} \text { (neutral) }\end{array}$ & [73] \\
\hline rGO-paste & $\begin{array}{l}\text { Cipro- } \\
\text { Floxacin }\end{array}$ & $\begin{array}{c}\mathrm{V}=400 \mathrm{~mL}, \mathrm{t}=45 \mathrm{~min} \\
\mathrm{E}=-0.62 \mathrm{~V}, 1.2 \mathrm{~L} \mathrm{~min} \mathrm{~min}^{-1} \mathrm{O}_{2}\end{array}$ & 0.0056 (acidic) & $\begin{array}{l}\mathrm{H}_{2} \mathrm{O}_{2}: 22 \mathrm{mg} \mathrm{L}^{-1} \\
\text { (acidic) }\end{array}$ & [72] \\
\hline $\begin{array}{c}\text { rGO } \\
\text { ink/carbon }\end{array}$ & Phenol & $\begin{array}{c}\mathrm{V}=80 \mathrm{~mL}, \mathrm{t}=120 \mathrm{~min} \\
0.2 \mathrm{~L} \mathrm{~min}^{-1} \text { air flow } \\
\mathrm{A}=6.3 \mathrm{~cm}^{2}, \mathrm{I}=1.25 \mathrm{~A} \mathrm{~cm}^{-2}\end{array}$ & 0.0157 (acidic) & $\begin{array}{c}\mathrm{H}_{2} \mathrm{O}_{2}: \\
2.81 \mathrm{mg} \mathrm{L}^{-1} \mathrm{~cm}^{-2}\end{array}$ & [71] \\
\hline $\begin{array}{l}\text { rGO/graphite } \\
\text { cloth }\end{array}$ & $\begin{array}{l}\text { Orange II } \\
\text { Methy blue } \\
\text { Sulfadiazine } \\
\text { Phenol }\end{array}$ & $\begin{array}{c}\mathrm{V}=100 \mathrm{~mL}, \mathrm{~A}=5.0 \mathrm{~cm}^{2} \\
\mathrm{E}=-0.9 \mathrm{~V}, \mathrm{t}=60 \mathrm{~min}\end{array}$ & $\begin{array}{l}0.52 \text { (acidic) } \\
0.37 \text { (acidic) } \\
0.62 \text { (acidic) } \\
0.37 \text { (acidic) }\end{array}$ & $\begin{array}{c}\mathrm{H}_{2} \mathrm{O}_{2}: \\
7.7 \mathrm{mg} \mathrm{h}^{-1} \mathrm{~cm}^{-2}(\mathrm{pH} 7) \\
2.2 \mathrm{mg} \mathrm{h}^{-1} \mathrm{~cm}^{-2}(\mathrm{pH} 5)\end{array}$ & [40] \\
\hline $\begin{array}{l}\text { Flow-cell } \\
\text { rGO }\end{array}$ & Sulfadiazine & $\begin{array}{l}\text { Flow through system, } \\
7 \mathrm{~mL} \min ^{-1}, \mathrm{I}=50 \mathrm{~mA}\end{array}$ & - & $\begin{array}{c}\mathrm{H}_{2} \mathrm{O}_{2}: \\
4.4 \mathrm{mg} \mathrm{h}^{-1} \mathrm{~cm}^{-2}(\mathrm{pH} 7)\end{array}$ & [3] \\
\hline $\mathrm{rGO} / \mathrm{C}$ felt & Imatinib & $\begin{array}{c}\mathrm{V}=150 \mathrm{~mL}, \mathrm{~A}=12 \mathrm{~cm}^{2}, \text { air } \\
\text { flow, } \mathrm{I}=16.6 \mathrm{~mA} \mathrm{~cm}^{-2} \\
\mathrm{t}=8 \mathrm{~h}\end{array}$ & 0.22 (acidic) & - & [55] \\
\hline $\begin{array}{c}\text { rGO dip } \\
\text { coated/C felt }\end{array}$ & $\begin{array}{l}\text { Cipro- } \\
\text { floxacin } \\
\text { Carba- } \\
\text { mazepine }\end{array}$ & $\begin{array}{c}\mathrm{V}=300 \mathrm{~mL} \text {, disc electrode } \\
80 \mathrm{~mm} \text { diameter, } \mathrm{E}=-1.5 \mathrm{~V}, \\
\mathrm{t}=180 \mathrm{~min} .\end{array}$ & $\begin{array}{c}0.37 \text { (acidic) } \\
0.20 \text { (neutral) } \\
0.35 \text { (acidic) } \\
0.08 \text { (neutral) }\end{array}$ & $\begin{array}{c}\mathrm{H}_{2} \mathrm{O}_{2}: \\
175 \mathrm{mg} \mathrm{L}^{-1}(\mathrm{pH} 7) \\
81 \mathrm{mg} \mathrm{L}^{-1}(\mathrm{pH} 3)\end{array}$ & [59] \\
\hline $\mathrm{rGO} / \mathrm{C}$ felt & $\begin{array}{l}\text { Reactive } \\
\text { Black } 5\end{array}$ & $\begin{array}{l}\mathrm{V}=250 \mathrm{~mL}, \mathrm{~A}=82 \mathrm{~cm}^{2} \\
\mathrm{E}=-0.65 \mathrm{~V}, \mathrm{t}=180 \mathrm{~min}\end{array}$ & - & $\mathrm{H}_{2} \mathrm{O}_{2}: 0.26 \mathrm{mM}$ & [57] \\
\hline $\begin{array}{l}\text { rGO C fibre } \\
\text { Brush }\end{array}$ & Phenol & $\begin{array}{c}\mathrm{V}=250 \mathrm{~mL}, \mathrm{~A}=46,665 \mathrm{~cm}^{2} \\
\mathrm{I}=1.25 \mathrm{~mA}, \mathrm{t}=180 \mathrm{~min}\end{array}$ & 0.06 (acidic) & $\begin{array}{c}\mathrm{H}_{2} \mathrm{O}_{2}: \\
4.23 \mathrm{mg} \mathrm{L}^{-1} \mathrm{~cm}^{-2}\end{array}$ & [6] \\
\hline $\begin{array}{l}\text { Optimised } \\
\text { graphite } \\
\text { system }\end{array}$ & & & & $\begin{array}{c}\mathrm{H}_{2} \mathrm{O}_{2}: \\
0.74 \mathrm{mg} \mathrm{h}^{-1} \mathrm{~cm}^{-2} \\
45 \mathrm{mg} \mathrm{L}^{-1}\end{array}$ & $\begin{array}{l}{[76]} \\
{[77]}\end{array}$ \\
\hline
\end{tabular}

\subsubsection{Graphene Aerogels}

Aerogels are three-dimensional highly porous materials and graphene-based aerogels exhibit interesting properties of high thermal stability, surface area and electrical conductivity [78]. They are readily constructed by the self-assembly of rGO to form a three-dimensional macroporous architecture [79,80], through template-guided approaches, solvothermal sol-gel reactions, or patterning technologies [81]. A schematic illustrating the formation of an aerogel from graphene-containing dispersions using the hydrothermal route is provided in Figure 3. The synthesised aerogel can be further processed, formed into discs and used as cathodes. These emerging materials are finding applications in fuel cells [82], environmental remediation [81,83], batteries [84] and, more recently, as electrodes in E-Fenton [85-87]. In particular, the aggregation and restacking of the rGO layers are minimised by the three-dimensional structure inside the bulk aerogel, giving good stability, while the surface layers are available to the electrolyte ions and target pollutant molecules and can be tailored for high pollutant adsorption. In addition, these materials are promising in heterogeneous E-Fenton, where zero-valent iron nanocrystals/nanoparticles or $\mathrm{Fe}_{3} \mathrm{O}_{4}$ nanoparticles can be embedded and protected within the aerogel [85]. A number of studies has been reported where rGO aerogels have been assembled and successfully used in E-Fenton for the removal of various contaminants [85,87-89]. 


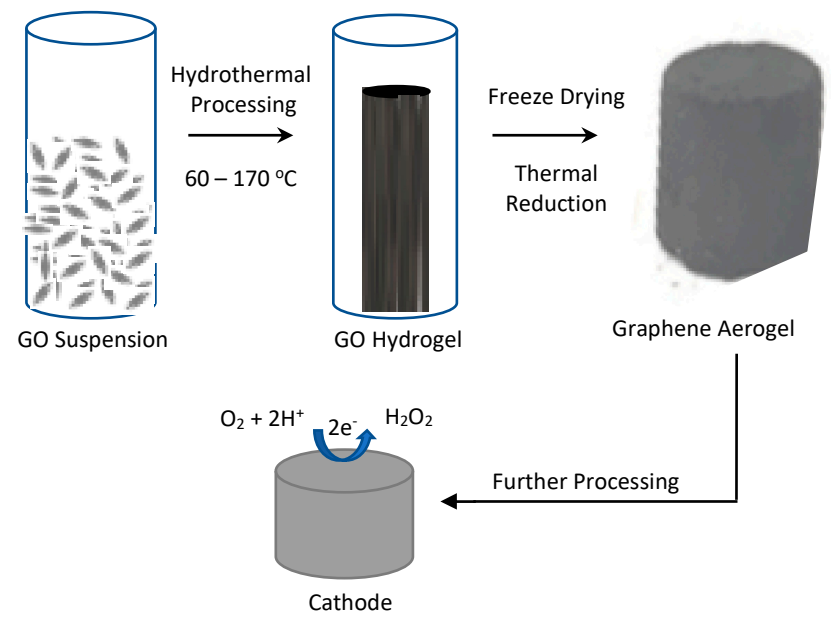

Figure 3. Schematic illustrating the formation of a graphene-based aerogel.

For example, Wen et al. [87] prepared three-dimensional macroporous rGO aerogels through the in situ assembly of rGO sheets. This electrode was employed as a cathode in E-Fenton to degrade the complex formed between ethylenediaminetetraacetic acid (EDTA) and $\mathrm{Ni}^{2+}$, EDTA-Ni. Using surface analytical techniques and adsorption measurements, the authors confirmed that the three-dimensional structure possessed homogenous macropores with a high surface area of $280.15 \mathrm{~m}^{2} \mathrm{~g}^{-1}$. The cathode showed enhanced electrocatalytic activity, leading to the efficient generation of $\mathrm{H}_{2} \mathrm{O}_{2}$ and regeneration of $\mathrm{Fe}^{2+}$. Likewise, Nazhif Mohd Nohan et al. [89] used a one-pot hydrothermal procedure to synthesise composites comprising CNTs and rGO aerogels. Studies revealed that the CNTs improved the surface area, pore volume and conductivity.

Graphene-based aerogels containing trapped $\mathrm{Fe}_{2} \mathrm{O}_{3}$ nanoparticles have also been successfully fabricated and employed in the heterogenous E-Fenton system for the degradation of Rhodamine $\mathrm{B}$ [88]. The addition of the $\mathrm{Fe}_{2} \mathrm{O}_{3}$ nanoparticles enhanced the degradation rate and this was attributed to the generation of $\mathrm{H}_{2} \mathrm{O}_{2}$ within the aerogel and the good diffusion and electrosorption of Rhodamine $\mathrm{B}$ within the aerogel to give high concentrations of the accumulated contaminant. The $\mathrm{H}_{2} \mathrm{O}_{2}$ was decomposed in the presence of $\mathrm{Fe}_{2} \mathrm{O}_{3}$ to give oxidising $\mathrm{OH}^{\bullet}$ with little quenching, as high concentrations of the pollutant were available. Chemical oxygen demand elimination rates up to $82 \%$ were observed, while a degradation rate of $99 \%$ was reached after $30 \mathrm{~min}$. Low iron leaching rates were observed even in acidic media and there was no significant loss in the catalytic activity over six cycles. In a separate study, a carbon aerogel with $\mathrm{rGO}, \mathrm{CNT}$ and iron oxide nanoparticles, $\mathrm{Fe}_{3} \mathrm{O}_{4}$, was formed successfully using a sol-gel process and then employed in an E-Fenton cell as a cathode in the degradation of methyl blue [85]. The good removal efficiency, reaching $99 \%$ after a $60 \mathrm{~min}$ period, was attributed to the high adsorption ability of the graphene-based composite and the added strength introduced by the CNTs.

\subsubsection{Three-Dimensional Graphene-Based Electrodes}

In terms of three-dimensional graphene-based materials, there is some evidence that threedimensional graphene-modified foams may be suitable in E-Fenton. In a comparison of graphene-based monolayer, multilayer and three-dimensional graphene-based foams as cathode materials in E-Fenton for wastewater treatment and the mineralisation of phenol, it was found that the three-dimensional foam exhibited the highest $\mathrm{H}_{2} \mathrm{O}_{2}$ electrogeneration yield, degradation and mineralisation rates [90]. The superiority of the three-dimensional graphene was attributed to its low interfacial charge transfer resistance, high surface area and porous structure. Interestingly, Roman et al. [28] have shown that a selective two-electron oxygen reduction reaction can be achieved with a selectivity of $94 \pm 2 \%$ using three-dimensional out-of-plane graphene edge sites. This was achieved by tuning the synthesis conditions to control the size and density of the out-of-plane graphene flakes and edges to provide a 
three-dimensional fuzzy graphene. In addition to the high selectivity, the onset potential was measured as $0.79 \mathrm{~V}$ vs. reversible hydrogen electrode (RHE).

\subsubsection{Three-Dimensional Graphene-Modified Electrodes}

Gas diffusion electrodes (GDE) are being used increasingly in fuel cells [91], batteries [92,93] and in the generation of $\mathrm{H}_{2} \mathrm{O}_{2}$ [94,95]. They are attractive in E-Fenton, as the solubility of dissolved oxygen is very low in water and, by using these GDE electrodes, the oxygen in air could be employed instead. The GDE electrode consists of a gas diffusion layer and the solid catalyst in contact with the aqueous phase, consisting of solid, liquid and gaseous phases. Normally, the catalyst layer is porous and the aerogels described in Section 2.2.1 are finding applications as catalyst layers, facilitating interactions between the liquid and gas phase. A schematic diagram illustrating the difference between the oxygen reduction reaction at a conventional cathode and at a gas diffusion electrode is presented in Figure 4 . As illustrated in this schematic, the air or gaseous phase is in contact with one side of the catalyst, enabling the diffusion of oxygen through the micropores of the diffusion layer to the catalyst phase, where it reacts with $\mathrm{H}^{+}$from the aqueous phase, while the conducting catalyst provides the electron, facilitating the formation of $\mathrm{H}_{2} \mathrm{O}_{2}$. Recently, this approach is finding applications in E-Fenton [96-98]. However, in many of these reports, pure oxygen is pumped to the surface of the gas diffusion cathode, rather than having the typical gas/air, solid and liquid phases, as illustrated in Figure 4.

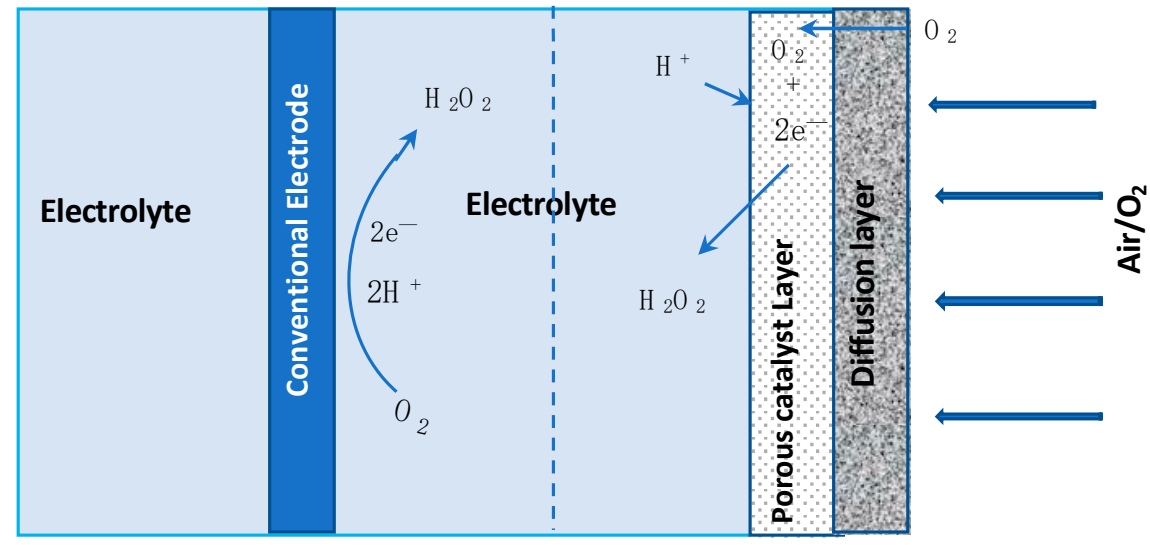

Figure 4. Schematic diagram of conventional solid-state electrode and porous gas diffusion electrode where the solid catalyst layer coexists with gas and liquid phases.

For example, a graphene-graphite diffusion electrode with high conductivity and electrocatalytic activity was formed for the continuous in situ generation of $\mathrm{H}_{2} \mathrm{O}_{2}$ through the oxygen reduction reaction, for the removal of Rhodamine B [56]. A removal rate of $98 \%$ was achieved after a $60 \mathrm{~min}$ period, which was higher than that obtained with a graphite-based gas diffusion cathode or graphite sheet cathode. The significant difference between the gas diffusion cathode and sheet cathode was attributed to the concentration of oxygen available for reaction, with the oxygen being supplied directly to the surface of the gas diffusion electrode, which, in turn, accelerated the generation rate of $\mathrm{H}_{2} \mathrm{O}_{2}$. The porous structure of the graphene-based diffusion electrode provided a reaction chamber for the efficient conversion of oxygen to $\mathrm{H}_{2} \mathrm{O}_{2}$. Liu et al. [98] used a graphene-based composite as a gas diffusion electrode for the removal of dimethyl phthalate from aqueous solution. Again, it was found that the $\mathrm{H}_{2} \mathrm{O}_{2}$ production was significantly improved. The apparent rate constant of dimethyl phthalate degradation was computed as $0.0322 \mathrm{~min}^{-1}$. The graphene-based diffusion electrode showed excellent recovery and could be reused. However, the degradation rate decreased slightly with increasing use and this was attributed to the blocking of the microspores and channels by iron sludge as the E-Fenton reaction proceeded. In another study, a gas diffusion electrode, consisting of a cylindrical body with a built in air diffuser, was fabricated using carbon cloth treated with PTFE and coated with electrochemically exfoliated rGO for the removal of industrial electronic wastewater [99]. High 
$\mathrm{H}_{2} \mathrm{O}_{2}$ concentrations of $495 \mathrm{mg} \mathrm{L}^{-1}$ were achieved to give a mineralisation rate of $80 \%$ over $80 \mathrm{~min}$. Gas diffusion electrodes have also been fabricated by combining $\mathrm{rGO}$ with $\mathrm{Fe}_{3} \mathrm{O}_{4}$ [7] and by using boron-doped graphene-based aerogels [100] for the removal of Bisphenol A. The combination of available $\mathrm{Fe}_{3} \mathrm{O}_{4}$ particles adjacent to the electrogenerated $\mathrm{H}_{2} \mathrm{O}_{2}$ facilitated the efficient generation of $\mathrm{OH}^{\bullet}$ and the removal of Bisphenol A [7]. A comparison of the aerogels, the porous three dimensional graphene-based composites and gas diffusion electrodes is summarised in Table 2, where it is evident that these materials have high surface areas, with a very good generation of $\mathrm{H}_{2} \mathrm{O}_{2}$, and they have been employed in the removal of several pollutants.

Table 2. Summary of porosity and $\mathrm{H}_{2} \mathrm{O}_{2}$ generation rate for various porous graphene-based composites.

\begin{tabular}{cccccc}
\hline System & $\begin{array}{c}\text { Surface } \\
\text { Area/ } \mathbf{m}^{\mathbf{2}} \mathbf{~ g}^{\mathbf{- 1}}\end{array}$ & $\begin{array}{c}\text { Pore } \\
\text { Diameter/nm }\end{array}$ & $\mathbf{H}_{\mathbf{2}} \mathbf{O}_{\mathbf{2}}$ & Pollutant & Ref. \\
\hline CNT/rGO & 256.9 & 16.9 & $100 \mathrm{mg} \mathrm{L}^{-1}$ & Methylene blue & {$[89]$} \\
3D rGO & 280.15 & 7.34 & - & EDTA-Ni & {$[87]$} \\
3D rGO foam & - & $(100-600) \times 10^{3}$ & $4.25 \mathrm{mg} \mathrm{L}^{-1} \mathrm{~cm}^{-3}$ & Phenol & {$[90]$} \\
rGO/GDC & 132 & - & $28.19 \mathrm{mg} \mathrm{h}^{-1} \mathrm{~cm}^{-2}$ & Nalidixic acid & {$[101]$} \\
FeOOH aerogel & $798-925$ & - & - & Sulfamethoxazole & {$[102]$} \\
rGO composite & 459 & 3.9 & $85 \mathrm{mg} \mathrm{L}^{-1}$ & Phthalic acid esters & {$[103]$} \\
\hline
\end{tabular}

While many studies indicate the superiority of graphene/rGO in fabricating gas diffusion electrodes, there are examples where other carbon-based systems exhibit a somewhat higher catalytic activity for the generation of $\mathrm{H}_{2} \mathrm{O}_{2}$. In a comparative study, tert-butyl-anthraquinone (TBAQ) was used to modify four different carbon materials, carbon aerogel, $\mathrm{CNT}$, carbon black and graphene-doped carbon black to fabricate gas diffusion electrodes for the production of $\mathrm{H}_{2} \mathrm{O}_{2}$ [104]. In this case, it was found that the highest $\mathrm{H}_{2} \mathrm{O}_{2}$ production and current efficiency were achieved with the CNT-gas diffusion electrode modified with $2 \%$ TBAQ, giving $2.15 \mathrm{mg} \mathrm{h}^{-1} \mathrm{~cm}^{-2}$ compared to $1.97 \mathrm{mg} \mathrm{cm}^{-2} \mathrm{~h}^{-1} \mathrm{of}_{2} \mathrm{O}_{2}$ for the corresponding graphene-based material. However, rates higher than $2.15 \mathrm{mg} \mathrm{h}^{-1} \mathrm{~cm}^{-2}$ can be seen in Table 2 for the graphene-based system. On the other hand, gas diffusion electrodes assembled using sulfur-doped carbon nanoparticles have been shown to exhibit superior electrocatalytic activity in an acidic medium for the oxygen reduction reaction [105].

\subsection{Doping of Graphene-Based Materials}

The doping of graphene/rGO, using heteroatoms such as $\mathrm{N}, \mathrm{B}, \mathrm{P}$ and $\mathrm{Fe}$, has been widely studied for the development of catalysts for the oxygen reduction reaction [106,107]. Depending on the preparation conditions employed and the nature of the dopants selected, the mechanism can vary from a two-electron to a four-electron pathway. Much of the research focus for environmental applications is directed at $\mathrm{N}$-doped graphene, as it has shown the more promising results, with many studies indicating that the presence of $\mathrm{N}$ enhances the production of $\mathrm{H}_{2} \mathrm{O}_{2}$ [108], while $\mathrm{Fe}$ and $\mathrm{P}$ co-doping favours the four-electron pathway [109]. Likewise, the addition of $\mathrm{P}$ and $\mathrm{B}$ to $\mathrm{N}$-doped graphene composites reduces the production of $\mathrm{H}_{2} \mathrm{O}_{2}$ [106]. As $\mathrm{N}$ has a higher electronegativity than $\mathrm{C}$, it attracts electrons, generating a partial positive charge on the $\mathrm{C}$ atoms, while $\mathrm{B}$ and $\mathrm{P}$ tend to donate electrons to the $\mathrm{C}$. Both these partial positive and partial negative charges should promote the adsorption of oxygen. However, little is known about the oxygen reduction reaction at $\mathrm{N}$-doped graphene composites or, indeed, the parameters that determine the selectivity of the oxygen reduction reaction at these materials. Several researchers have hypothesised that oxygen adsorbs through a side-on orientation on $\mathrm{N}$-doped carbon $[110,111]$. However, it has also been shown from theoretical calculations that this side-on adsorption is unlikely and that end-on adsorption is more favourable $[112,113]$. The three main forms of $\mathrm{N}$ in N-doped graphene are pyridinic, pyrrolic and graphitic. Some authors claim that it is the graphitic $\mathrm{N}$ sites that facilitate oxygen adsorption and therefore the oxygen reduction reaction [112,114], while others have proposed that it is the pyridinic $\mathrm{N}$ that improves the chemisorption of oxygen [115]. 
It has also been shown that oxygen adsorption occurs on the carbon atoms at edges and these are far removed from the graphitic $\mathrm{N}$ atoms, making it difficult to explain how $\mathrm{N}$ doping facilitates the oxygen reduction reaction.

The four-electron transfer pathway is normally observed in alkaline solutions [107], while, in acidic environments, two-electron transfer is the more favoured reaction for carbon-based materials [116]. However, some $\mathrm{N}$-doped or $\mathrm{N}$-treated graphene-based electrodes have been found to catalyse the four-electron reduction in aqueous acid solutions [117,118]. Kurak and Anderson [119] have used a linear Gibbs energy relationship applied to N-doped graphene composites to predict the reversible potential for the formation of oxygen reduction reaction intermediates in acid. These authors concluded that there was no clear pathway for the direct four-electron reduction reaction, suggesting that transition metal impurities may be responsible for the observed direct four-electron pathway. Indeed, it has been suggested that the presence of $\mathrm{Cu}$ in $\mathrm{N}$-doped graphene-based materials favours the two-electron pathway, but traces of $\mathrm{Ti}, \mathrm{Mo}, \mathrm{Nb}$ and $\mathrm{Ru}$ favour four-electron transfer [120]. Liu et al. [121] showed that by varying the $\mathrm{N}$-doping temperature and microwave heating power, the number of electrons in the oxygen reduction reaction can be controlled, giving a two-electron reaction for the electrochemical degradation of organic contaminants, or the preferred four-electron transfer reaction for applications in metal air batteries. It has also been shown that the selectivity can be controlled by the degree of oxidation, with the more oxidised graphene facilitating a two-electron reduction pathway to give $\mathrm{H}_{2} \mathrm{O}_{2}$, but on reduction with $\mathrm{NaBH}_{4}$, the same materials exhibit more selectivity for the four-electron pathway [122]. Kim et al. [123] suggested that the generation of $\mathrm{H}_{2} \mathrm{O}_{2}$ is connected with epoxy or ether groups in the $\mathrm{N}$-doped rGO, while N-doped graphene composites, with abundant quaternary nitrogen species, show the selectivity of the two-electron reduction pathway; however, with pyridinic species, the four-electron pathway is preferred [124]. These studies highlight that, while the two-electron transfer reaction can be achieved with graphene or N-doped graphene-based materials, the selectivity of this reaction depends on how the graphene composite is formed and processed. Moreover, various methods have been employed in doping graphene-based materials with $\mathrm{N}$ and this may also influence the mechanism of the oxygen reduction reaction.

A number of $\mathrm{N}$-doped graphene-based electrodes have been employed successfully in E-Fenton. Li and Zhang [39] employed N-doped graphene and N-doped graphene-graphite felt cathodes in the removal of phenacetin from wastewater, while $\mathrm{Fe} / \mathrm{N}$-doped graphene loaded with $\mathrm{Fe} / \mathrm{Fe}_{3} \mathrm{C}$ nanoparticles was used for the removal of phenol, methanol, acetone, dichloromethane and diethyl phthalate from real samples [125]. The authors concluded that the $\mathrm{Fe} / \mathrm{Fe}_{3} \mathrm{C}$ nanoparticles were encapsulated and protected, preventing the aggregation or leakage of the $\mathrm{Fe}$, while the high-surface-area porous framework, with abundant channels and pores, provided access for the pollutants, while facilitating the formation of $\mathrm{H}_{2} \mathrm{O}_{2}$. A gas diffusion cathode was formed with $\mathrm{N}$-doped graphene composites and CNTs for the removal of dimethyl phthalate [98]. The authors showed that the oxygen reduction reaction was facilitated with $\mathrm{N}$-doping of the graphene composite, with the effective generation of $\mathrm{H}_{2} \mathrm{O}_{2}$ at a relatively low potential of $0.2 \mathrm{~V}$ vs. SCE. Yang et al. [126] employed $\mathrm{N}$-doped graphene/graphite felt electrodes for the efficient generation of $\mathrm{OH}^{\bullet}$, with a high yield of $6.2 \mathrm{mg} \mathrm{h}^{-1} \mathrm{~cm}^{-2}$ of $\mathrm{H}_{2} \mathrm{O}_{2}$. $\mathrm{Su}$ et al. [54] obtained an even higher yield of $\mathrm{H}_{2} \mathrm{O}_{2}$, reaching a value of $8.6 \mathrm{mg} \mathrm{h}^{-1} \mathrm{~cm}^{-2}$, with a selectivity of $78 \%$ at neutral $\mathrm{pH}$ and a low energy consumption of $9.8 \mathrm{~kW} \mathrm{~h} \mathrm{~kg}^{-1}$. In another recent study [127], N-doped graphene-based catalysts were found to accelerate the production of $\mathrm{H}_{2} \mathrm{O}_{2}$ and the generation of $\mathrm{OH}^{\bullet}$. This $\mathrm{N}$-doped graphene-modified graphite felt electrode was used in the mineralisation of 2,4-dichlorophenoxiacetic acid with an impressive rate of $88 \%$ at a $\mathrm{pH}$ of 7.0 after $480 \mathrm{~min}$.

Graphene-based aerogels, where the graphene was doped with $\mathrm{N}$ and also co-doped with $\mathrm{N}$ and $\mathrm{S}$ were compared as cathodes in a heterogeneous E-Fenton cell [128]. The highest pollutant removal rate was observed with the $\mathrm{N}$-doped graphene-based aerogels combined with a carbon- $\mathrm{Fe}_{3} \mathrm{O}_{4}$ catalyst, giving a removal rate of $71 \%$, a mineralisation rate of $51 \%$ with good stability and low iron leaching of $0.33 \mathrm{mg} \mathrm{L}^{-1}$. Interestingly, it was observed that the N/S-doped graphene facilitated the four-electron 
oxygen reduction reaction, while it was mainly the two-electron pathway that was observed with the $\mathrm{N}$-doped graphene-based aerogel. While N-doped graphene appears to be superior in the promotion of the two-electron oxygen reduction reaction, Wu et al. [100] have shown that B-doped graphene-based materials may also have applications as cathodes in E-Fenton cells.

\subsection{Graphene-Based Materials Combined with CNTs}

Graphene/GO can be easily combined with a variety of other components such as metal oxides [129], metal nanoparticles [130] and metal organic frameworks [131]. While the addition of conducting metals or metal oxides can enhance the overall conductivity of the composite, metal-free carbon-based materials have considerable advantages in terms of cost and this has led to the development of graphene and CNT composites. CNTs can be combined with graphene-based materials to further enhance the electrocatalytic activity and conductivity, while acting as a structural support that prevents the graphene-modified sheets or flakes from restacking. These materials are finding applications in the fabrication of cathodes for E-Fenton and in the removal of contaminants. Bridged N-doped graphene and CNT composites, with microscopic three-dimensional structures, have been employed as gas diffusion electrodes and have been shown to enhance the oxygen reduction reaction, compared to graphene-based electrodes, CNT and graphite [98]. Other approaches include binder-free CNTs and graphene-based aerogel electrodes [89], iron oxide-containing CNTs, graphene-based aerogels [85] and graphene combined with CNTs on carbon felt electrodes [57]. In each of these cases, the addition of CNTs has been shown to be beneficial and to enable the more efficient removal of the contaminants.

\subsection{Graphene-Based Materials Combined with Iron Oxides and Other Metal Oxides}

As detailed earlier, the homogeneous E-Fenton reaction use the $\mathrm{Fe}^{2+/} \mathrm{Fe}^{3+}$ couple to catalytically decompose $\mathrm{H}_{2} \mathrm{O}_{2}$ into $\mathrm{OH}^{\bullet}$, a potent oxidant (and possibly $\mathrm{OOH}^{\bullet}$, which is a much weaker oxidising agent). While the $\mathrm{Fe}^{2+}$ and $\mathrm{Fe}^{3+}$ are soluble in acidic solutions, with any increase in $\mathrm{pH}$, for example through the four-electron reduction at the cathode (Equation (4)), insoluble iron hydroxides begin to form, reducing the concentration of $\mathrm{Fe}^{2+}$ ions that are needed for the E-Fenton reaction. This is readily seen from the Pourbaix diagram presented in Figure 5, where the predicted stability phases of the soluble $\mathrm{Fe}^{2+}$ and $\mathrm{Fe}^{3+}$ are shown as a function of $\mathrm{pH}$. The dashed lines show the $\mathrm{pH}$ dependence of the oxygen reduction and hydrogen ion reduction reactions.

Moreover, the reaction rate of $\mathrm{Fe}^{3+}$ to $\mathrm{Fe}^{2+}$ is approximately 6000 times slower than the oxidation of $\mathrm{Fe}^{2+}$ to $\mathrm{Fe}^{3+}$, which inhibits efficient recycling between the $\mathrm{Fe}^{2+}$ and $\mathrm{Fe}^{3+}$ ions [1,132]. In addition, a large mass of iron-containing sludge is formed when the solution is neutralised. These issues can be largely resolved by using heterogenous E-Fenton [11,133]. In this case, solid iron-containing catalysts are immobilised onto a support, which helps to prevent the leaching of iron from the catalyst, minimising sludge formation, giving a wider working $\mathrm{pH}$ range and a more efficient conversion of $\mathrm{Fe}^{3+}$ to $\mathrm{Fe}^{2+}$ in the solid-state catalyst. As shown in Figure 5, at low $\mathrm{pH}$ values, leaching and dissolution are more significant, while this dissolution reaction becomes negligible as the $\mathrm{pH}$ is increased to neutral or slightly alkaline values. However, the principal aim in heterogeneous E-Fenton is to eliminate the dissolution of iron and the introduction of metal ions into the treated water. In Table 3, iron leaching rates are shown for different graphene-based materials together with the $\mathrm{H}_{2} \mathrm{O}_{2}$ or $\mathrm{OH}^{\bullet}$ concentrations formed, where it is seen that relatively low leaching rates can be achieved. 


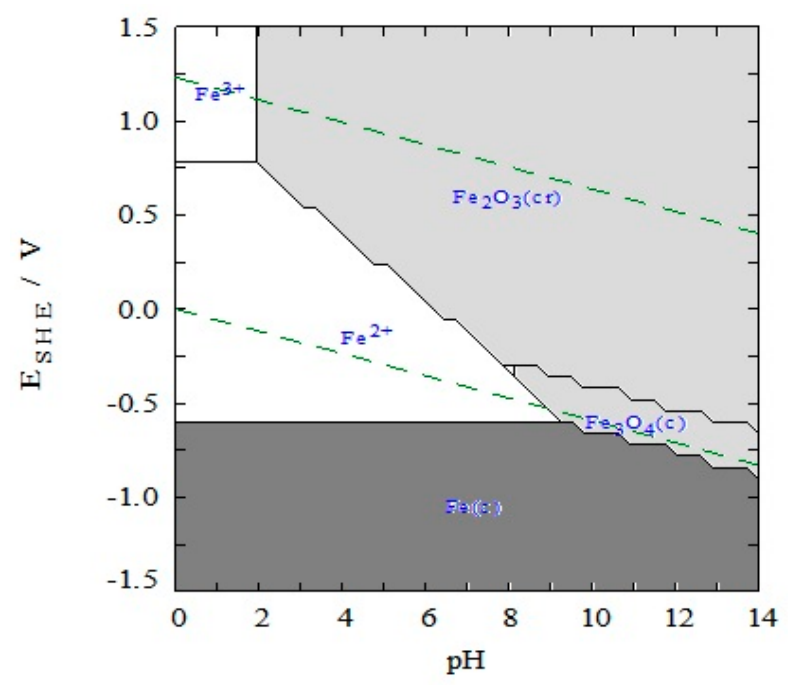

Figure 5. Pourbaix diagram for iron in water (dissolved iron concentration is $1.0 \times 10^{-5} \mathrm{M}$ at $298 \mathrm{~K}$ ). Only $\mathrm{Fe}, \mathrm{Fe}_{3} \mathrm{O}_{4}, \mathrm{Fe}_{2} \mathrm{O}_{3}$ are considered as the solid products, generated with the MEDUSA software based on the SOLGASWATER algorithm [134].

Table 3. Leaching rates of iron from iron-containing graphene-based composites.

\begin{tabular}{ccccc}
\hline System & Iron Leaching & $\mathbf{H}_{\mathbf{2}} \mathbf{O}_{\mathbf{2}}$ & $\mathbf{O H}^{\bullet}$ & Ref. \\
\hline $\mathrm{Fe} / \mathrm{Cu} / \mathrm{FeO}_{2} / \mathrm{rGO}$ & $2.0-3.1 \%$ & $47.78 \mu \mathrm{M}$ & - & {$[135]$} \\
$\mathrm{Fe}_{3} \mathrm{O}_{4} / \mathrm{rGO}$ & $<1 \%, 0.02 \mathrm{mg} \mathrm{L}^{-1}$ & - & $177.2 \mu \mathrm{M}$ & {$[65]$} \\
$\mathrm{Fe}_{3} \mathrm{O}_{4} / \mathrm{rGO}$ & $2.4 \%$ & - & - & {$[136]$} \\
$\mathrm{Fe}_{3} \mathrm{O}_{4} / \mathrm{rGO}$ & $0.02 \mathrm{mg} \mathrm{L}^{-1}$ & - & - & {$[137]$} \\
$\mathrm{Fe}_{3} \mathrm{O}_{4} / \mathrm{N}-\mathrm{rGO}, \mathrm{GDC}$ & $<9.5 \%, 0.009 \mathrm{mM}$ & - & $64 \mu \mathrm{M}$ & {$[7]$} \\
$\mathrm{Fe}_{2} \mathrm{O}_{3} / \mathrm{rGO}$ aerogel & $2.3 \mathrm{mg} \mathrm{L}^{-1}$ & $4.3 \mathrm{mg} \mathrm{L}^{-1}$ & - & {$[88]$} \\
$\mathrm{Fe}_{3} \mathrm{O}_{4} / \mathrm{CNT}-\mathrm{rGO}$ & $<2 \mathrm{mg} \mathrm{L}^{-1}$ & $40 \mathrm{mg} \mathrm{L}^{-1}$ & - & {$[85]$} \\
$\mathrm{Fe}_{3} \mathrm{O}_{4} / \mathrm{N}-\mathrm{rGO}$ aerogel & $0.33 \mathrm{mg} \mathrm{L}^{-1}$ & - & - & {$[128]$} \\
\hline
\end{tabular}

The oxides $\mathrm{Fe}_{2} \mathrm{O}_{3}, \mathrm{Fe}_{3} \mathrm{O}_{4}$ and $\mathrm{FeOOH}$, and ferrocene, which all contain the $\mathrm{Fe}^{2+} / \mathrm{Fe}^{3+}$ redox pair, have been employed [138-140], while graphene-containing composites have been combined with $\mathrm{Fe}_{3} \mathrm{O}_{4}$ [141,142], FeOOH [102], zero valent iron [143] and ferrocene [58]. In a recent study, Wang et al. [102] fabricated an $\gamma$-FeOOH graphene-polyacrylamide-carbonised aerogel (GPCA) for the degradation of sulfamethoxazole. The synthesised $\gamma$-FeOOH GPCA cathode had very good conductivity, a high surface area and very good dispersion of the iron component, which facilitated the regeneration of $\mathrm{Fe}^{2+}$. This system was employed at a neutral $\mathrm{pH}$ to give a total organic carbon removal efficiency of $89 \%$. Zero-valent iron has also been encapsulated within a three-dimensional graphene-based network to give a catalyst for the adsorption and degradation of sulfadiazine [143]. Iron oxide nanoparticles wrapped in graphene-based aerogel with $\alpha-\mathrm{Fe}_{2} \mathrm{O}_{3}$ as the iron source have also been employed in heterogenous E-Fenton [88]. In this case, efficient removal of Rhodamine B was observed, with low iron leaching $\left(<2.3 \mathrm{mg} \mathrm{L}^{-1}\right)$ in acidic solutions.

The iron oxide, $\mathrm{Fe}_{3} \mathrm{O}_{4}$, has been used more widely as the iron-containing catalyst [141,144]. For example, a quinone-functionalised graphene-based electrode modified with well-dispersed $\mathrm{Fe}_{3} \mathrm{O}_{4}$ nanoparticles was employed for the continuous electrogeneration of $\mathrm{H}_{2} \mathrm{O}_{2}$ and $\mathrm{OH}^{\bullet}$. A degradation efficiency of $98 \%$ was observed for the removal of Bisphenol A within 90 min at neutral pH with less than $1 \%$ of iron leaching [65]. Akerdi et al. [141] have also employed well-dispersed $\mathrm{Fe}_{3} \mathrm{O}_{4}$ nanoparticles on $\mathrm{GO}$ and $\mathrm{rGO}$ to enhance the removal of two dyes, methylene blue and acid red. Shen et al. [145] have employed graphene- $\mathrm{Fe}_{3} \mathrm{O}_{4}$ hollow hybrid microspheres, while graphene oxide- $\mathrm{Fe}_{3} \mathrm{O}_{4}$ was employed as a heterogeneous catalyst for the E-Fenton degradation of two antibiotics, chloramphenicol and metronidazole [137]. $\mathrm{Fe}_{3} \mathrm{O}_{4}$ particles have also been utilised with $\mathrm{N}$-doped graphene-based aerogels 
for the degradation of acetaminophen with a low iron leaching of $0.33 \mathrm{mg} \mathrm{L}^{-1}$ in heterogeneous E-Fenton [128]. These iron oxides have also been combined with graphene/CNT aerogel for the degradation of methyl blue [85]. In a more recent study, the efficient decomposition of Bisphenol A was achieved with a gas diffusion electrode and $\mathrm{Fe}_{3} \mathrm{O}_{4}$ particles at $\mathrm{N}$-doped $\mathrm{rGO}$ as catalytic particle electrodes. The $\mathrm{Fe}_{3} \mathrm{O}_{4} / \mathrm{N}-\mathrm{rGO}$ also served as the heterogeneous catalyst, resulting in the rapid regeneration of $\mathrm{Fe}^{2+}$ and high concentrations of $\mathrm{OH}^{\bullet}$ oxidants [7].

There is also increasing interest in finding iron-free or, indeed, metal-free catalysts for heterogeneous E-Fenton. An iron-free $\mathrm{rGO} / \mathrm{MoS}_{2} / \mathrm{Ce}_{0.75} \mathrm{Zr}_{0.25} \mathrm{O}_{2}$ composite was fabricated and used for the effective removal of ciprofloxacin. The decomposition of $\mathrm{H}_{2} \mathrm{O}_{2}$ to generate $\mathrm{OH}^{\bullet}$ was facilitated by the redox pair $\mathrm{Ce}^{3+} / \mathrm{Ce}^{4+}$ to give complete removal of ciprofloxacin within $5 \mathrm{~h}$, with a mineralisation rate of $77 \%$ in $3 \mathrm{~h} \mathrm{[146].} \mathrm{HKUST} \mathrm{(metal} \mathrm{organic} \mathrm{framework)-derived} \mathrm{Cu} \mathrm{nanoparticles} \mathrm{were} \mathrm{embedded}$ within a three-dimensional rGO network to give the E-Fenton catalyst [147]. It was proposed that the zero-valent $\mathrm{Cu}$ was oxidised to $\mathrm{Cu}^{+}$, which then catalysed the decomposition of the electrogenerated $\mathrm{H}_{2} \mathrm{O}_{2}$ to give $\mathrm{OH}^{\bullet}$ and as a result the $\mathrm{Cu}^{+}$was converted to $\mathrm{Cu}^{2+}$. The conducting catalyst layer, serving as the cathode, facilitated the reduction of $\mathrm{Cu}^{2+}$ to generate $\mathrm{Cu}^{+}$, leading to the efficient recycling of the $\mathrm{Cu}^{+} / \mathrm{Cu}^{2+}$ redox couple. Metal-free E-Fenton has also been recently proposed, as graphitic and pyridinic $\mathrm{N}$ sites on graphene-based materials appear to function as active sites for both the electrogeneration of $\mathrm{H}_{2} \mathrm{O}_{2}$ and the activation of $\mathrm{OH}^{\bullet}$ radicals $[54,126,148]$.

\section{Conclusions and Future Perspectives}

Graphene-based materials have attracted considerable interest, both from a fundamental viewpoint and in terms of their potential applications, and this family is one of the most studied, surpassing all other two-dimensional materials. It is no surprise that these materials are now finding applications in E-Fenton and, when combined with other carbon-based materials, they have the potential to give true iron- and metal-free E-Fenton catalysts. This would have a significant impact in terms of cost and environmental concerns. As shown earlier, rGO can be employed effectively in several ways, supported onto carbon or graphite electrodes or cloth, combined with CNTs, iron and other metal oxide catalysts, formed as aerogels and used in gas diffusion electrodes and doped with $\mathrm{N}$ and other elements, with $\mathrm{N}$-doping appearing to be the best option in E-Fenton. It certainly appears that GO, with its very good conductivity when reduced to give $\mathrm{rGO}$, high surface area, and good stability, will be used increasingly in future research in E-Fenton, leading to new and exciting developments. While the electrocatalytic generation of $\mathrm{H}_{2} \mathrm{O}_{2}$ is considered as an undesirable product in many research fields, such as batteries and fuel cells, tailoring the properties of the graphene-based composite with doping or by combining it with other materials to give a two-electron oxygen reduction reaction has significant potential not only in E-Fenton, but there are a number of other technologies, such as antimicrobial, medical, bleaching, gas scrubbing and refinery applications, that would benefit from the in situ generation of $\mathrm{H}_{2} \mathrm{O}_{2}$, eliminating the need for its storage.

In order for E-Fenton to emerge and be well integrated into real wastewater treatment facilities, new and more efficient Fenton catalysts are required. While heterogenous E-Fenton addresses many of the limitations of homogeneous E-Fenton, more efficient catalysts that are capable of generating high yields of $\mathrm{H}_{2} \mathrm{O}_{2}$, while catalysing the efficient conversion of $\mathrm{H}_{2} \mathrm{O}_{2}$ into $\mathrm{OH}^{\bullet}$, reducing or eliminating the release of metal ions, such as $\mathrm{Fe}^{3+}$ or $\mathrm{Fe}^{2+}$, into the water, are required. These catalysts will also need to exhibit high stability, enabling their use over multiple E-Fenton cycles, with low energy demand. This will require the development of new Fenton catalysts and graphene composites have a clear role to play in these developments, most likely in terms of composites formed using other new and emerging materials, including other two-dimensional materials, and by doping.

In terms of possible new materials that could, in the future, be combined with graphene-based materials, MXenes deserve a special mention. These are exciting two-dimensional materials $[149,150]$ that could be combined with graphene-based materials and possibly exploited in E-Fenton. Indeed, it has been shown that the MXenes have a high density of oxygen adsorption sites [151]. The 
further development of three-dimensional graphene composites is another interesting possibility. The three-dimensional framework gives high porosity, high surface area and facilitates ion diffusion, with numerous active sites that can enhance the rate of electron transfer. This approach could be further refined with the appropriate heteroatom doping of graphene composites. While $\mathrm{N}$-doped graphene has been employed successfully in E-Fenton, dual or multiple dopants may exert even more beneficial effects. Halogen doping, F, Cl, Br and I, has been used to tailor the catalytic activity of carbon and graphene-based composites [152]. The charge accumulation at the doped halogens create a strong dipole [153] and this may enhance the adsorption of oxygen, making halogen doping interesting for E-Fenton applications. The recent use of gas diffusion electrodes is also important, as these electrodes have the potential to deliver much higher amounts of oxygen to the Fenton catalyst. It is very clear that the application of graphene-based materials in E-Fenton is still in its infancy and new developments will be seen in the next decade.

However, the application of graphene-based materials, as composites, or combined with other materials, and/or with doping, in E-Fenton has a number of challenges that must be overcome before significant advances are made. While remarkable progress has been made in the synthesis of graphene flakes, GO and rGO, a cost-effective large-scale synthesis is needed before these applications become a reality. The cost effective production of graphene and its oxides is required, but control over reproducibility and quality is equally important. Wet graphite exfoliation methods, including chemical and electrochemical processes, are promising in terms of scalability and cost, but concerns still remain over the reproducibility of these approaches and the quality of the final graphene product. Nevertheless, there is evidence to show that the oxygen reduction reaction is promoted at graphene edges, rather than basal planes, making these wet graphite exfoliation methods possibly suitable for the scaling up and production of graphene-based cathodes that can be employed in E-Fenton.

It is also difficult to precisely control the doping levels of graphene-based materials. At another level, there are some concerns in terms of the environmental impact of GO and its potential adverse effects on aquatic ecosystems [154]. In particular, GO contains polar oxygen-containing groups, making it more soluble in water. These environmental concerns need to be addressed by fabricating highly stable graphene-based cathodes that prevent the leaching of GO flakes into the environment. Secondly, cathodes containing a graphene-based catalyst will require regeneration or some suitable disposal to prevent secondary pollution.

Nevertheless, with further advancements in the synthesis, scale-up and processing of graphene-based composites and electrodes, it is very likely that new Fenton catalysts and, indeed, metal-free Fenton catalysts can be fabricated, leading to innovations in advanced oxidation processes for the protection of water resources.

Author Contributions: The authors, T.Y. and C.B.B., contributed equally in producing this review. All authors have read and agreed to the published version of the manuscript.

Funding: This research was funded by the Irish Research Council.

Conflicts of Interest: The authors declare no conflict of interest.

\section{References}

1. Zhang, M.-H.; Dong, H.; Zhao, L.; Wang, D.-X.; Meng, D. A review on Fenton process for organic wastewater treatment based on optimization perspective. Sci. Total Environ. 2019, 670, 110-121. [CrossRef] [PubMed]

2. Zhao, X.; Liu, S.; Huang, Y. Removing organic contaminants by an electro-Fenton system constructed with graphene cathode. Toxicol. Environ. Chem. 2016, 98, 530-539. [CrossRef]

3. Ren, G.; Zhou, M.; Su, P.; Yang, W.; Lu, X.; Zhang, Y. Simultaneous sulfadiazines degradation and disinfection from municipal secondary effluent by a flow-through electro-Fenton process with graphene-modified cathode. J. Hazard. Mater. 2019, 368, 830-839. [CrossRef] [PubMed] 
4. Mi, X.; Han, J.; Sun, Y.; Li, Y.; Hu, W.; Zhan, S. Enhanced catalytic degradation by using RGO-Ce/WO 3 nanosheets modified CF as electro-Fenton cathode: Influence factors, reaction mechanism and pathways. J. Hazard. Mater. 2019, 367, 365-374. [CrossRef] [PubMed]

5. Li, X.; Liu, F.; Zhang, W.; Lu, H.; Zhang, J. Electrocatalytical oxidation of arsenite by reduced graphene oxide via in-situ electrocatalytic generation of $\mathrm{H}_{2} \mathrm{O}_{2}$. Environ. Pollut. 2019, 254, 112958. [CrossRef]

6. Mousset, E.; Wang, Z.; Hammaker, J.; Lefebvre, O. Electrocatalytic phenol degradation by a novel nanostructured carbon fiber brush cathode coated with graphene ink. Electrochim. Acta 2017, 258, $607-617$. [CrossRef]

7. Zhang, Y.; Chen, Z.; Wu, P.; Duan, Y.; Zhou, L.; Lai, Y.; Wang, F.; Li, S. Three-dimensional heterogeneous Electro-Fenton system with a novel catalytic particle electrode for Bisphenol A removal. J. Hazard. Mater. 2020, 393, 120448. [CrossRef]

8. Hammouda, S.B.; Fourcade, F.; Assadi, A.; Soutrel, I.; Adhoum, N.; Amrane, A.; Monser, L. Effective heterogeneous electro-Fenton process for the degradation of a malodorous compound, indole, using iron loaded alginate beads as a reusable catalyst. Appl. Catal. B Environ. 2016, 82, 47-58. [CrossRef]

9. Tang, Q.; Wang, D.; Yao, D.; Yang, C.; Sun, Y. Heterogeneous electro-Fenton oxidation of p-nitrophenol with a reusable fluffy clump steel wire. Desalin. Water Treat. 2016, 57, 15475-15485. [CrossRef]

10. Iglesias, O.; Meijide, J.; Bocos, E.; Sanromán, M.Á.; Pazos, M. New approaches on heterogeneous electro-Fenton treatment of winery wastewater. Electrochim. Acta 2015, 169, 134-141. [CrossRef]

11. Ganiyu, S.O.; Zhou, M.; Martínez-Huitle, C.A. Heterogeneous electro-Fenton and photoelectro-Fenton processes: A critical review of fundamental principles and application for water/wastewater treatment. Appl. Catal. B Environ. 2018, 235, 103-129. [CrossRef]

12. Waldt, C.T.; Ananthaneni, S.; Rankin, R.B. Towards quaternary alloy Au-Pd catalysts for direct synthesis of hydrogen peroxide. Mater. Today Energy 2020, 16, 100399. [CrossRef]

13. Kim, S.; Lee, D.-W.; Lee, K.-Y. Direct synthesis of hydrogen peroxide from hydrogen and oxygen over single-crystal cubic palladium on silica catalysts. J. Mol. Catal. A Chem. 2014, 383, 64-69. [CrossRef]

14. Wang, N.; Zheng, T.; Zhang, G.; Wang, P. A review on Fenton-like processes for organic wastewater treatment. J. Environ. Chem. Eng. 2016, 4, 762-787. [CrossRef]

15. Brillas, E.; Martínez-Huitle, C.A. Decontamination of wastewaters containing synthetic organic dyes by electrochemical methods. An updated review. Appl. Catal. B Environ. 2015, 166, 603-643. [CrossRef]

16. Babuponnusami, A.; Muthukumar, K. A review on Fenton and improvements to the Fenton process for wastewater treatment. J. Environ. Chem. Eng. 2014, 2, 557-572. [CrossRef]

17. Moreira, F.C.; Boaventura, R.A.R.; Brillas, E.; Vilar, V.J.P. Electrochemical advanced oxidation processes: A review on their application to synthetic and real wastewaters. Appl. Catal. B Environ. 2017, 202, $217-261$. [CrossRef]

18. Nidheesh, P.V.; Zhou, M.; Oturan, M.A. An overview on the removal of synthetic dyes from water by electrochemical advanced oxidation processes. Chemosphere 2018, 197, 210-227. [CrossRef]

19. Le, T.X.H.; Bechelany, M.; Cretin, M. Carbon felt based-electrodes for energy and environmental applications: A review. Carbon 2017, 122, 564-591.

20. Nag, A.; Mitra, A.; Mukhopadhyay, S.C. Graphene and its sensor-based applications: A review. Sens. Actuators A Phys. 2018, 270, 177-194. [CrossRef]

21. Chang, Y.-M.; Lin, H.-W.; Li, L.-J.; Chen, H.-Y. Two-dimensional materials as anodes for sodium-ion batteries. Mater. Today Adv. 2020, 6, 100054. [CrossRef]

22. Jin, H.; Guo, C.; Liu, X.; Liu, J.; Vasileff, A.; Jiao, Y.; Zheng, Y.; Qiao, S.Z. Emerging two-dimensional nanomaterials for electrocatalysis. Chem. Rev. 2018, 118, 6337-6408. [CrossRef] [PubMed]

23. Geng, P.; Zheng, S.; Tang, H.; Zhu, R.; Zhang, L.; Cao, S.; Xue, H.; Pang, H. Transition metal sulfides based on graphene for electrochemical energy storage. Adv. Energy Mater. 2018, 8, 1703259. [CrossRef]

24. Li, D.; Lai, W.-Y.; Zhang, Y.-Z.; Huang, W. Printable transparent conductive films for flexible electronics. Adv. Mater. 2018, 30, 1704738. [CrossRef]

25. Divyapriya, G.; Nidheesh, P.V. Importance of Graphene in the Electro-Fenton Process. ACS Omega 2020, 5, 4725-4732. [CrossRef]

26. Li, J.; Li, X.; Chen, H.; Xiao, D.; Li, J.; Xu, D. Fe, N dual doped graphitic carbon derived from straw as efficient electrochemical catalysts for oxygen reduction reaction and $\mathrm{Zn}$-air batteries. J. Electroanal. Chem. 2020, 865, 114133. [CrossRef] 
27. Wang, N.; Ma, S.; Duan, J.; Zhai, X.; Guan, F.; Wang, X.; Hou, B. Electrocatalytic oxygen reduction to hydrogen peroxide by oxidized graphene aerogel supported cubic $\mathrm{MnCO}_{3}$ for antibacteria in neutral media. Electrochim. Acta 2020, 340, 135880. [CrossRef]

28. San Roman, D.; Krishnamurthy, D.; Garg, R.; Hafiz, H.; Lamparski, M.; Nuhfer, N.T.; Meunier, V.; Viswanathan, V.; Cohen-Karni, T. Engineering three-dimensional (3d) out-of-plane graphene edge sites for highly selective two-electron oxygen reduction electrocatalysis. ACS Catal. 2020, 10, 1993-2008. [CrossRef]

29. Zhou, W.; Meng, X.; Gao, J.; Alshawabkeh, A.N. Hydrogen peroxide generation from $\mathrm{O}_{2}$ electroreduction for environmental remediation: A state-of-the-art review. Chemosphere 2019, 225, 588-607. [CrossRef]

30. Rocha, R.S.; Valim, R.B.; Trevelin, L.C.; Steter, J.R.; Carneiro, J.F.; Forti, J.C.; Bertazzoli, R.; Lanza, M.R.V. Electrocatalysis of hydrogen peroxide generation using oxygen-fed gas diffusion electrodes made of carbon black modified with quinone compounds. Electrocatalysis 2020. [CrossRef]

31. Kim, H.W.; Bukas, V.J.; Park, H.; Park, S.; Diederichsen, K.M.; Lim, J.; Cho, Y.H.; Kim, J.; Kim, W.; Han, T.H.; et al. Mechanisms of two-electron and four-electron electrochemical oxygen reduction reactions at nitrogen-doped reduced graphene oxide. ACS Catal. 2020, 10, 852-863. [CrossRef]

32. Sánchez-Sánchez, C.M.; Bard, A.J. Hydrogen peroxide production in the oxygen reduction reaction at different electrocatalysts as quantified by scanning electrochemical microscopy. Anal. Chem. 2009, 81, 8094-8100. [CrossRef] [PubMed]

33. Vasudevan, S.; Oturan, M.A. Electrochemistry: As cause and cure in water pollution-an overview. Environ. Chem. Lett. 2014, 12, 97-108. [CrossRef]

34. Sirés, I.; Brillas, E.; Oturan, M.A.; Rodrigo, M.A.; Panizza, M. Electrochemical advanced oxidation processes: Today and tomorrow. A review. Environ. Sci. Pollut. Res. 2014, 21, 8336-8367. [CrossRef]

35. Khataee, A.; Sajjadi, S.; Pouran, S.R.; Hasanzadeh, A.; Joo, S.W. A comparative study on electrogeneration of hydrogen peroxide through oxygen reduction over various plasma-treated graphite electrodes. Electrochim. Acta 2017, 244, 38-46. [CrossRef]

36. Randviir, E.P.; Banks, C.E. The oxygen reduction reaction at graphene modified electrodes. Electroanalysis 2014, 26, 76-83. [CrossRef]

37. Kim, H.W.; Ross, M.B.; Kornienko, N.; Zhang, L.; Guo, J.; Yang, P.; McCloskey, B.D. Efficient hydrogen peroxide generation using reduced graphene oxide-based oxygen reduction electrocatalysts. Nat. Catal. 2018, 1, 282-290. [CrossRef]

38. Ma, X.-X.; Su, Y.; He, X.-Q. Fe $\mathrm{S}_{10}$-decorated N, S co-doped graphene as a new and efficient electrocatalyst for oxygen reduction and oxygen evolution reactions. Catal. Sci. Technol. 2017, 7, 1181-1192. [CrossRef]

39. Li, G.; Zhang, Y. Highly selective two-electron oxygen reduction to generate hydrogen peroxide using graphite felt modified with N-doped graphene in an electro-Fenton system. New J. Chem. 2019, 43, 12657-12667. [CrossRef]

40. Yang, W.; Zhou, M.; Cai, J.; Liang, L.; Ren, G.; Jiang, L. Ultrahigh yield of hydrogen peroxide on graphite felt cathode modified with electrochemically exfoliated graphene. J. Mater. Chem. A 2017, 5, 8070-8080. [CrossRef]

41. Zhang, C.J.; Nicolosi, V. Graphene and MXene-based transparent conductive electrodes and supercapacitors. Energy Storage Mater. 2019, 16, 102-125. [CrossRef]

42. Dreyer, D.R.; Park, S.; Bielawski, C.W.; Ruoff, R.S. The chemistry of graphene oxide. Chem. Soc. Rev. 2010, 39, 228-240. [CrossRef] [PubMed]

43. Eigler, S.; Hirsch, A. Chemistry with graphene and graphene oxide-Challenges for synthetic chemists. Angew. Chem. Int. Ed. 2014, 53, 7720-7738. [CrossRef] [PubMed]

44. Dideikin, A.T.; Vul', A.Y. Graphene oxide and derivatives: The place in graphene family. Front. Phys. 2019, 6, 149. [CrossRef]

45. Hummers, W.S.; Offeman, R.E. Preparation of graphitic oxide. J. Am. Chem. Soc. 1958, 80, 1339. [CrossRef]

46. Eda, G.; Chhowalla, M. Chemically derived graphene oxide: Towards large-area thin-film electronics and optoelectronics. Adv. Mater. 2010, 22, 2392-2415. [CrossRef]

47. Pei, S.; Cheng, H.-M. The reduction of graphene oxide. Carbon N. Y. 2012, 50, 3210-3228. [CrossRef]

48. Zhang, J.; Yang, H.; Shen, G.; Cheng, P.; Zhang, J.; Guo, S. Reduction of graphene oxide vial-ascorbic acid. Chem. Commun. 2010, 46, 1112-1114. [CrossRef] 
49. Wang, Z.; Zhou, X.; Zhang, J.; Boey, F.; Zhang, H. Direct electrochemical reduction of single-layer graphene oxide and subsequent functionalization with glucose oxidase. J. Phys. Chem. C 2009, 113, 14071-14075. [CrossRef]

50. Guo, H.-L.; Wang, X.-F.; Qian, Q.-Y.; Wang, F.-B.; Xia, X.-H. A green approach to the synthesis of graphene nanosheets. ACS Nano 2009, 3, 2653-2659. [CrossRef]

51. Shao, Y.; Wang, J.; Engelhard, M.; Wang, C.; Lin, Y. Facile and controllable electrochemical reduction of graphene oxide and its applications. J. Mater. Chem. 2010, 20, 743-748. [CrossRef]

52. Le, T.X.H.; Bechelany, M.; Champavert, J.; Cretin, M. A highly active based graphene cathode for the electro-fenton reaction. RSC Adv. 2015, 5, 42536-42539. [CrossRef]

53. Gao, Y.; Zhu, W.; Wang, C.; Zhao, X.; Shu, M.; Zhang, J.; Bai, H. Enhancement of oxygen reduction on a newly fabricated cathode and its application in the electro-Fenton process. Electrochim. Acta 2020, 330, 135206. [CrossRef]

54. Su, P.; Zhou, M.; Lu, X.; Yang, W.; Ren, G.; Cai, J. Electrochemical catalytic mechanism of N-doped graphene for enhanced $\mathrm{H}_{2} \mathrm{O}_{2}$ yield and in-situ degradation of organic pollutant. Appl. Catal. B Environ. 2019, 245, 583-595. [CrossRef]

55. Yang, W.; Zhou, M.; Oturan, N.; Li, Y.; Oturan, M.A. Electrocatalytic destruction of pharmaceutical imatinib by electro-Fenton process with graphene-based cathode. Electrochim. Acta 2019, 305, 285-294. [CrossRef]

56. Zhang, Z.; Meng, H.; Wang, Y.; Shi, L.; Wang, X.; Chai, S. Fabrication of graphene@graphite-based gas diffusion electrode for improving $\mathrm{H}_{2} \mathrm{O}_{2}$ generation in Electro-Fenton process. Electrochim. Acta 2018, 260, 112-120. [CrossRef]

57. Wang, Y.-T.; Tu, C.-H.; Lin, Y.-S. Application of graphene and carbon nanotubes on carbon felt electrodes for the electro-fenton system. Materials 2019, 12, 1698. [CrossRef]

58. Divyapriya, G.; Nambi, I.; Senthilnathan, J. Ferrocene functionalized graphene-based electrode for the electro-Fenton oxidation of ciprofloxacin. Chemosphere 2018, 209, 113-123. [CrossRef]

59. Divyapriya, G.; Srinivasan, R.; Nambi, I.M.; Senthilnathan, J. Highly active and stable ferrocene functionalized graphene encapsulated carbon felt array-A novel rotating disc electrode for electro-Fenton oxidation of pharmaceutical compounds. Electrochim. Acta 2018, 283, 858-870. [CrossRef]

60. Xu, X.; Chen, J.; Zhang, G.; Song, Y.; Yang, F. Homogeneous electro-fenton oxidative degradation of reactive brilliant blue using a graphene doped gas-diffusion cathode. Int. J. Electrochem. Sci. 2014, 9, 569-579.

61. Luo, J.; Tung, V.C.; Koltonow, A.R.; Jang, H.D.; Huang, J. Graphene oxide based conductive glue as a binder for ultracapacitor electrodes. J. Mater. Chem. 2012, 22, 12993-12996. [CrossRef]

62. Le, T.X.H.; Bechelany, M.; Lacour, S.; Mehmet, N.O.; MarcCretin, A.O. High removal efficiency of dye pollutants by electron-Fenton process using a graphene-based cathode. Carbon N. Y. 2015, 94, 1003-1011. [CrossRef]

63. Liu, Z.; Rios-Carvajal, T.; Ceccato, M.; Hassenkam, T. Nanoscale chemical mapping of oxygen functional groups on graphene oxide using atomic force microscopy-coupled infrared spectroscopy. J. Colloid Interface Sci. 2019, 556, 458-465. [CrossRef]

64. Aliyev, E.; Filiz, V.; Khan, M.M.; Lee, Y.J.; Abetz, C.; Abetz, V. Structural characterization of graphene oxide: Surface functional groups and fractionated oxidative debris. Nanomaterials 2019, 9, 1180. [CrossRef]

65. Divyapriya, G.; Nambi, I.M.; Senthilnathan, J. An innate quinone functionalized electrochemically exfoliated graphene $/ \mathrm{Fe}_{3} \mathrm{O}_{4}$ composite electrode for the continuous generation of reactive oxygen species. Chem. Eng. J. 2017, 316, 964-977. [CrossRef]

66. Guo, H.; Wang, Z.; Yang, W.; Li, J.; Jiang, D. A facile ratiometric electrochemical sensor for sensitive 4-acetamidophenol determination based on ferrocene-graphene oxide-Nafion modified electrode. Anal. Methods 2020, 12, 1353-1359. [CrossRef]

67. Wang, X.; Qi, Y.; Shen, Y.; Yuan, Y.; Zhang, L.; Zhang, C.; Sun, Y. A ratiometric electrochemical sensor for simultaneous detection of multiple heavy metal ions based on ferrocene-functionalized metal-organic framework. Sens. Actuators B Chem. 2020, 310, 127756. [CrossRef]

68. Liu, Y.; Li, K.; Xu, W.; Du, B.; Wei, Q.; Liu, B.; Wei, D. GO/PEDOT:NaPSS modified cathode as heterogeneous electro-Fenton pretreatment and subsequently aerobic granular sludge biological degradation for dye wastewater treatment. Sci. Total Environ. 2020, 700, 134536. [CrossRef]

69. Kamyshny, A.; Magdassi, S. Conductive nanomaterials for 2D and 3D printed flexible electronics. Chem. Soc. Rev. 2019, 48, 1712-1740. [CrossRef] 
70. Huang, Q.; Zhu, Y. Printing conductive nanomaterials for flexible and stretchable electronics: A review of materials, processes, and applications. Adv. Mater. Technol. 2019, 4, 1800546. [CrossRef]

71. Mousset, E.; Ko, Z.T.; Syafiq, M.; Wang, Z.; Lefebvre, O. Electrocatalytic activity enhancement of a graphene ink-coated carbon cloth cathode for oxidative treatment. Electrochim. Acta 2016, 222, 1628-1641. [CrossRef]

72. Rani, V.; Das, R.K.; Golder, A.K. Fabrication of reduced graphene oxide-graphite paste electrode for $\mathrm{H}_{2} \mathrm{O}_{2}$ formation and its implication for ciprofloxacin degradation. Surf. Interfaces 2017, 7, 99-105. [CrossRef]

73. Divyapriya, G.; Thangadurai, P.; Nambi, I. Green approach to produce a graphene thin film on a conductive LCD matrix for the oxidative transformation of ciprofloxacin. ACS Sustain. Chem. Eng. 2018, 6, 3453-3462. [CrossRef]

74. Huong Le, T.X.; Dumee, L.F.; Lacour, S.; Rivallin, M.; Yi, Z.; Kong, L.; Bechelany, M.; Cretin, M. Hybrid graphene-decorated metal hollow fibre membrane reactors for efficient electro-Fenton-Filtration co-processes. J. Memb. Sci. 2019, 587, 117182. [CrossRef]

75. Jiang, W.-L.; Xia, X.; Han, J.-L.; Ding, Y.-C.; Haider, M.R.; Wang, A.-J. Graphene modified electro-Fenton catalytic membrane for in situ degradation of antibiotic florfenicol. Environ. Sci. Technol. 2018, 52, 9972-9982. [CrossRef]

76. Yu, F.; Tao, L.; Cao, T. High yield of hydrogen peroxide on modified graphite felt electrode with nitrogen-doped porous carbon carbonized by zeolitic imidazolate framework-8 (ZIF-8) nanocrystals. Environ. Pollut. 2019, 255, 113119. [CrossRef]

77. Zhou, W.; Rajic, L.; Meng, X.; Nazari, R.; Zhao, Y.; Wang, Y.; Gao, J.; Qin Alshawabkeh, N. Efficient $\mathrm{H}_{2} \mathrm{O}_{2}$ electrogeneration at graphite felt modified via electrode polarity reversal: Utilization for organic pollutants degradation. Chem. Eng. J. 2019, 364, 428-439. [CrossRef]

78. Cong, H.-P.; Ren, X.-C.; Wang, P.; Yu, S.-H. Macroscopic multifunctional graphene-based hydrogels and aerogels by a metal ion induced self-assembly process. ACS Nano 2012, 6, 2693-2703. [CrossRef]

79. Nardecchia, S.; Carriazo, D.; Ferrer, M.L.; Gutiérrez, M.C.; Del Monte, F. Three dimensional macroporous architectures and aerogels built of carbon nanotubes and/or graphene: Synthesis and applications. Chem. Soc. Rev. 2013, 42, 794-830. [CrossRef]

80. Li, C.; Shi, G. Three-dimensional graphene architectures. Nanoscale 2012, 4, 5549-5563. [CrossRef]

81. Wang, H.; Yan, X.; Zeng, G.; Wu, Y.; Liu, Y.; Jiang, Q.; Gu, S. Three-dimensional graphene-based materials: Synthesis and applications from energy storage and conversion to electrochemical sensor and environmental remediation. Adv. Colloid Interface Sci. 2015, 221, 41-59. [CrossRef]

82. Cavallo, C.; Agostini, M.; Genders, J.P.; Abdelhamid, M.E.; Matic, A. A free-standing reduced graphene oxide aerogel as supporting electrode in a fluorine-free $\mathrm{Li}_{2} \mathrm{~S}_{8}$ catholyte Li-S battery. J. Power Sources 2019, 416, 111-117. [CrossRef]

83. Zhao, L.; Wang, Z.-B.; Li, J.-L.; Zhang, J.-J.; Sui, X.-L.; Zhang, L.-M. Hybrid of carbon-supported Pt nanoparticles and three-dimensional graphene aerogel as high stable electrocatalyst for methanol electrooxidation. Electrochim. Acta 2016, 189, 175-183. [CrossRef]

84. Jiang, T.; Bu, F.; Feng, X.; Shakir, I.; Hao, G.; Xu, Y. Porous $\mathrm{Fe}_{2} \mathrm{O}_{3}$ nanoframeworks encapsulated within three-dimensional graphene as high-performance flexible anode for lithium-ion battery. ACS Nano 2017, 11, 5140-5147. [CrossRef]

85. Chen, W.; Yang, X.; Huang, J.; Zhu, Y.; Zhou, Y.; Yao, Y.; Li, C. Iron oxide containing graphene/carbon nanotube-based carbon aerogel as an efficient E-Fenton cathode for the degradation of methyl blue. Electrochim. Acta 2016, 200, 75-83. [CrossRef]

86. Zhao, H.; Wang, Q.; Chen, Y.; Tian, Q.; Zhao, G. Efficient removal of dimethyl phthalate with activated iron-doped carbon aerogel through an integrated adsorption and electro-Fenton oxidation process. Carbon N. Y. 2017, 124, 111-122. [CrossRef]

87. Wen, S.; Niu, Z.; Zhang, Z.; Li, L.; Chen, Y. In-situ synthesis of 3D GA on titanium wire as a binder-free electrode for electro-Fenton removing of EDTA-Ni. J. Hazard. Mater. 2018, 341, 128-137. [CrossRef]

88. Cao, X.; Jiang, D.; Huang, M.; Pan, J.; Lin, J.; Chan, W. Iron oxide nanoparticles wrapped in graphene aerogel composite: Fabrication and application in electro-fenton at a wide pH. Colloids Surf. A Physicochem. Eng. Asp. 2020, 587, 124269. [CrossRef]

89. Nazhif Mohd Nohan, M.A.; Chia, C.H.; Hashimi, A.S.; Chin, S.X.; Khiew, P.S.; Azmi, A.; Laua, K.S.; Razalia, N.F. Highly stable binder free CNTs/rGO aerogel electrode for decolouration of methylene blue and palm oil mill effluent via electro-Fenton oxidation process. RSC Adv. 2019, 9, 16472-16478. [CrossRef] 
90. Mousset, E.; Wang, Z.; Hammaker, J.; Lefebvre, O. Physico-chemical properties of pristine graphene and its performance as electrode material for electro-Fenton treatment of wastewater. Electrochim. Acta 2016, 214, 217-230. [CrossRef]

91. Bidault, F.; Brett, D.J.L.; Middleton, P.H.; Brandon, N.P. Review of gas diffusion cathodes for alkaline fuel cells. J. Power Sources 2009, 187, 39-48. [CrossRef]

92. Maja, M.; Orecchia, C.; Strano, M.; Tosco, P.; Vanni, M. Effect of structure of the electrical performance of gas diffusion electrodes for metal air batteries. Electrochim. Acta 2000, 46, 423-432. [CrossRef]

93. Tran, C.; Yang, X.-Q.; Qu, D. Investigation of the gas-diffusion-electrode used as lithium/air cathode in non-aqueous electrolyte and the importance of carbon material porosity. J. Power Sources 2010, 195, 2057-2063. [CrossRef]

94. Moreira, J.; Bocalon Lima, V.; Athie Goulart, L.; Lanza, M.R.V. Electrosynthesis of hydrogen peroxide using modified gas diffusion electrodes (MGDE) for environmental applications: Quinones and azo compounds employed as redox modifiers. Appl. Catal. B Environ. 2019, 248, 95-107. [CrossRef]

95. Tang, Q.; Wang, D.; Yao, D.M.; Yang, C.W.; Sun, Y.C. Highly efficient electro-generation of hydrogen peroxide using NCNT/NF/CNT air diffusion electrode for electro-Fenton degradation of p-nitrophenol. Water Sci. Technol. 2016, 73, 1652-1658. [CrossRef]

96. Yatagai, T.; Ohkawa, Y.; Kubo, D.; Kawase, Y. Hydroxyl radical generation in electro-Fenton process with a gas-diffusion electrode: Linkages with electro-chemical generation of hydrogen peroxide and iron redox cycle. J. Environ. Sci. Heal. Part A Toxic Hazard. Subst. Environ. Eng. 2017, 52, 74-83. [CrossRef]

97. Yu, X.; Zhou, M.; Ren, G.; Ma, L. A novel dual gas diffusion electrodes system for efficient hydrogen peroxide generation used in electro-Fenton. Chem. Eng. J. 2015, 263, 92-100. [CrossRef]

98. Liu, T.; Wang, K.; Song, S.; Brouzgou, A.; Tsiakaras, P.; Wang, Y. New electro-Fenton gas diffusion cathode based on nitrogen-doped graphene@carbon nanotube composite materials. Electrochim. Acta 2016, 194, 228-238. [CrossRef]

99. Garcia-Rodriguez, O.; Yang Lee, L.; Olvera-Vargasa, H.; Deng, F.; Wang, Z.; Lefebvrea, O. Mineralization of electronic wastewater by electro-Fenton with an enhanced graphene-based gas diffusion cathode. Electrochim. Acta 2018, 276, 12-20. [CrossRef]

100. Wu, P.; Zhang, Y.; Chen, Z.; Duan, Y.; Lai, Y.; Fang, Q.; Wang, F.; Li, S. Performance of boron-doped graphene aerogel modified gas diffusion electrode for in-situ metal-free electrochemical advanced oxidation of Bisphenol A. Appl. Catal. B Environ. 2019, 255, 117784. [CrossRef]

101. Zarei, M.; Beheshti Nahand, F.; Khataee, A.; Hasanzadeh, A. Removal of nalidixic acid from aqueous solutions using a cathode containing three-dimensional graphene. J. Water Process Eng. 2019, 32, 100978. [CrossRef]

102. Wang, Y.; Zhang, H.; Li, B.; Yu, M.; Zhao, R.; Xu, X.; Cai, L. $\gamma$-FeOOH graphene polyacrylamide carbonized aerogel as air-cathode in electro-Fenton process for enhanced degradation of sulfamethoxazole. Chem. Eng. J. 2019, 359, 914-923. [CrossRef]

103. Ren, W.; Tang, D.; Lu, X.; Sun, J.; Li, M.; Qiu, S.; Fan, D. Novel multilayer ACF@rGO@OMC cathode composite with enhanced activity for electro-Fenton degradation of phthalic acid esters. Ind. Eng. Chem. Res. 2016, 55, 11085-11096. [CrossRef]

104. Lu, X.; Zhou, M.; Li, Y.; Su, P.; Cai, J.; Pan, Y. Improving the yield of hydrogen peroxide on gas diffusion electrode modified with tert-butyl-anthraquinone on different carbon support. Electrochim. Acta 2019, 320, 134552. [CrossRef]

105. Kamaraj, R.; Vasudevan, S. Sulfur-doped carbon chain network as high-performance electrocatalyst for electro-Fenton system. ChemistrySelect 2019, 4, 2428-2435. [CrossRef]

106. Choi, C.H.; Chung, M.W.; Kwon, H.C.; Park, S.H.; Woo, S.I. B, N- and P, N-doped graphene as highly active catalysts for oxygen reduction reactions in acidic media. J. Mater. Chem. A 2013, 1, 3694-3699. [CrossRef]

107. Dumont, J.H.; Martinez, U.; Artyushkova, K.; Purdy, G.M.; Dattelbaum, A.M.; Zelenay, P.; Mohite, A.; Atanassov, P.; Gupta, G. Nitrogen-doped graphene oxide electrocatalysts for the oxygen reduction reaction. ACS Appl. Nano Mater. 2019, 2, 1675-1682. [CrossRef]

108. Zheng, B.; Cai, X.-L.; Zhou, Y.; Xia, X.-H. Pure Pyridinic Nitrogen-Doped Single-Layer Graphene Catalyzes Two-Electron Transfer Process of Oxygen Reduction Reaction. ChemElectroChem 2016, 3, 2036-2042. [CrossRef]

109. He, F.; Li, K.; Xie, G.; Wang, Y.; Jiao, M.; Tang, H.; Wu, Z. Theoretical insights on the catalytic activity and mechanism for oxygen reduction reaction at Fe and P codoped graphene. Phys. Chem. Chem. Phys. 2016, 18, 12675-12681. [CrossRef] 
110. Li, J.-C.; Hou, P.-X.; Liu, C. Heteroatom-doped carbon nanotube and graphene-based electrocatalysts for oxygen reduction reaction. Small 2017, 13, 1702002. [CrossRef]

111. Feng, L.; Yan, Y.; Chen, Y.; Wang, L. Nitrogen-doped carbon nanotubes as efficient and durable metal-free cathodic catalysts for oxygen reduction in microbial fuel cells. Energy Environ. Sci. 2011, 4, 1892-1899. [CrossRef]

112. Ikeda, T.; Boero, M.; Huang, S.-F.; Terakura, K.; Oshima, M.; Ozaki, J. Carbon alloy catalysts: Active sites for oxygen reduction reaction. J. Phys. Chem. C 2008, 112, 14706-14709. [CrossRef]

113. Sidik, R.A.; Anderson, A.B.; Subramanian, N.P.; Kumaraguru, S.P.; Popov, B.N. $\mathrm{O}_{2}$ reduction on graphite and nitrogen-doped graphite: Experiment and theory. J. Phys. Chem. 2006, 110, 1787-1793. [CrossRef]

114. Vazquez-Arenas, J.; Galano, A.; Lee, D.U.; Higgins, D.; Guevara-Garcia, A.; Chen, Z. Theoretical and experimental studies of highly active graphene nanosheets to determine catalytic nitrogen sites responsible for the oxygen reduction reaction in alkaline media. J. Mater. Chem. A 2016, 4, 976-990. [CrossRef]

115. Sun, M.; Wu, X.; Xie, Z.; Deng, X.; Wen, J.; Huang, O.; Huang, B. Tailoring platelet carbon nanofibers for high-purity Pyridinic-N doping: A novel method for synthesizing oxygen reduction reaction catalysts. Carbon, N. Y. 2017, 125, 401-408. [CrossRef]

116. Noffke, B.W.; Li, Q.; Raghavachari, K.; Li, L.-S. A Model for the pH-dependent selectivity of the oxygen reduction reaction electrocatalyzed by N-doped graphitic carbon. J. Am. Chem. Soc. 2016, 138, 13923-13929. [CrossRef]

117. Kong, D.; Yuan, W.; Li, C.; Song, J.; Xie, A.; Shen, Y. Synergistic effect of Nitrogen-doped hierarchical porous carbon/graphene with enhanced catalytic performance for oxygen reduction reaction. Appl. Surf. Sci. 2017, 393, 144-150. [CrossRef]

118. Liu, Q.; Zhang, H.; Zhong, H.; Zhang, S.; Chen, S. N-doped graphene/carbon composite as non-precious metal electrocatalyst for oxygen reduction reaction. Electrochim. Acta 2012, 81, 313-320. [CrossRef]

119. Kurak, K.A.; Anderson, A.B. Nitrogen-treated graphite and oxygen electroreduction on pyridinic edge sites. J. Phys. Chem. C 2009, 113, 6730-6734. [CrossRef]

120. Bhatt, M.D.; Lee, G.; Lee, J.S. Density Functional Theory (DFT) Calculations for oxygen reduction reaction mechanisms on metal-, nitrogen- co-doped graphene ( $\mathrm{M}-\mathrm{N}_{2}-\mathrm{G}(\mathrm{M}=\mathrm{Ti}, \mathrm{Cu}, \mathrm{Mo}, \mathrm{Nb}$ and $\mathrm{Ru})$ ) electrocatalysts. Electrochim. Acta 2017, 228, 619-627. [CrossRef]

121. Liu, C.L.; Hu, C.-C.; Wu, S.-H.; Wu, T.-H. Electron transfer number control of the oxygen reduction reaction on nitrogen-doped reduced-graphene oxides using experimental design strategies. J. Electrochem. Soc. 2013, 160, H547-H552. [CrossRef]

122. Favaro, M.; Carraro, F.; Cattelan, M.; Colazzo, L.; Durante, C.; Sambi, M.; Gennaro, A.; Agnoli, S.; Granozzi, G. Multiple doping of graphene oxide foams and quantum dots: New switchable systems for oxygen reduction and water remediation. J. Mater. Chem. A 2015, 3, 14334-14347. [CrossRef]

123. Kim, H.W.; Park, H.; Roh, J.S.; Shin, J.E.; Lee, T.H.; Zhang, L.; Cho, Y.H.; Yoon, H.W.; Bukas, V.J.; Guo, J.; et al. Carbon Defect Characterization of Nitrogen-Doped Reduced Graphene Oxide Electrocatalysts for the Two-Electron Oxygen Reduction Reaction. Chem. Mater. 2019, 31, 3967-3973. [CrossRef]

124. Yasuda, S.; Yu, L.; Kim, J.; Murakoshi, K. Selective nitrogen doping in graphene for oxygen reduction reactions. Chem. Commun. 2013, 49, 9627-9629. [CrossRef] [PubMed]

125. Huang, X.; Niu, Y.; Hu, W. Fe/Fe ${ }_{3} \mathrm{C}$ nanoparticles loaded on $\mathrm{Fe} / \mathrm{N}$-doped graphene as an efficient heterogeneous Fenton catalyst for degradation of organic pollutants. Coll. Surf. A Physicochem. Eng. Asp. 2017, 518, 145-150. [CrossRef]

126. Yang, W.; Zhou, M.; Liang, L. Highly efficient in-situ metal-free electrochemical advanced oxidation process using graphite felt modified with $\mathrm{N}$-doped graphene. Chem. Eng. J. 2018, 338, 700-708. [CrossRef]

127. Yang, W.; Zhou, M.; Oturan, N.; Li, Y.; Su, P.; Oturan, M.A. Enhanced activation of hydrogen peroxide using nitrogen doped graphene for effective removal of herbicide 2,4-D from water by iron-free electrochemical advanced oxidation. Electrochim. Acta 2019, 297, 582-592. [CrossRef]

128. Fernández-Sáez, N.; Villela-Martinez, D.E.; Carrasco-Marín, F.; Pérez-Cadenas, A.F.; Pastrana-Martínez, L.M. Heteroatom-doped graphene aerogels and carbon-magnetite catalysts for the heterogeneous electro-Fenton degradation of acetaminophen in aqueous solution. J. Catal. 2019, 378, 68-79. [CrossRef]

129. Tong, Y.; Chen, P.; Zhou, T.; Xu, K.; Chu, W.; Wu, C.; Xie, Y. A bifunctional hybrid electrocatalyst for oxygen reduction and evolution: Cobalt oxide nanoparticles strongly coupled to B, N-decorated graphene. Angew. Chemie Int. Ed. 2017, 56, 7121-7125. [CrossRef] 
130. Bagheri, H.; Hajian, A.; Rezaei, M.; Shirzadmehr, A. Composite of Cu metal nanoparticles-multiwall carbon nanotubes-reduced graphene oxide as a novel and high performance platform of the electrochemical sensor for simultaneous determination of nitrite and nitrate. J. Hazard. Mater. 2017, 324, 762-772. [CrossRef]

131. Xu, Y.; Tu, W.; Zhang, B.; Yin, S.; Huang, Y.; Kraft, M.; Xu, R. Nickel nanoparticles encapsulated in few-layer nitrogen-doped graphene derived from metal-organic frameworks as efficient bifunctional electrocatalysts for overall water splitting. Adv. Mater. 2017, 29, 1605957. [CrossRef]

132. Martínez-Huitle, C.A.; Rodrigo, M.A.; Sirés, I.; Scialdone, O. Single and coupled electrochemical processes and reactors for the abatement of organic water pollutants: A critical review. Chem. Rev. 2015, 115, 13362-13407. [CrossRef] [PubMed]

133. Poza-Nogueiras, V.; Rosales, E.; Pazos, M.; Sanromán, M. Current advances and trends in electro-Fenton process using heterogeneous catalysts-A review. Chemosphere 2018, 201, 399-416. [CrossRef] [PubMed]

134. Eriksson, G. An algorithm for the computation of aqueous multi-component, multiphase equilibria. Anal. Chim. Acta 1979, 112, 375-383. [CrossRef]

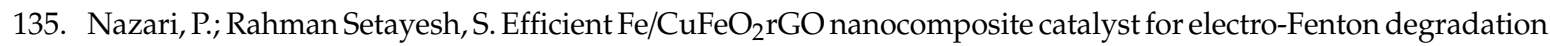
of organic pollutant: Preparation, characterization and optimization. Appl. Organomet. Chem. 2019, 33, e5138. [CrossRef]

136. Nazari, P.; Setayesh, S.R. Effective degradation of Reactive Red 195 via heterogeneous electro-Fenton treatment: Theoretical study and optimization. Int. J. Environ. Sci. Technol. 2019, 16, 6329-6346. [CrossRef]

137. Görmez, F.; Görmez, Ö.; Gözmen, B.; Kalderis, D. Degradation of chloramphenicol and metronidazole by electro-Fenton process using graphene oxide- $\mathrm{Fe}_{3} \mathrm{O}_{4}$ as heterogeneous catalyst. J. Environ. Chem. Eng. 2019, 7, 102990. [CrossRef]

138. Zhang, G.; Wang, S.; Yang, F. Efficient adsorption and combined heterogeneous/homogeneous fenton oxidation of Amaranth using supported nano-FeOOH as cathodic catalysts. J. Phys. Chem. C 2012, 116, 3623-3634. [CrossRef]

139. Özcan, A.; Atılır Özcan, A.; Demirci, Y.; Şener, E. Preparation of $\mathrm{Fe}_{2} \mathrm{O}_{3}$ modified kaolin and application in heterogeneous electro-catalytic oxidation of enoxacin. Appl. Catal. B Environ. 2017, 200, 361-371. [CrossRef]

140. Sun, M.; Ru, X.-R.; Zhai, L.-F. In-situ fabrication of supported iron oxides from synthetic acid mine drainage: High catalytic activities and good stabilities towards electro-Fenton reaction. Appl. Catal. B Environ 2015, 165, 103-110. [CrossRef]

141. Akerdi, A.G.; Es'Haghzade, Z.; Bahrami, S.H.; Arami, M. Comparative study of GO and reduced GO coated graphite electrodes for decolorization of acidic and basic dyes from aqueous solutions through heterogeneous electro-Fenton process. J. Environ. Chem. Eng. 2017, 5, 2313-2324. [CrossRef]

142. Wu, Z.-S.; Yang, S.; Sun, Y.; Parvez, K.; Feng, X.; Mullen, K. 3D nitrogen-doped graphene aerogel-supported $\mathrm{Fe}_{3} \mathrm{O}_{4}$ nanoparticles as efficient electrocatalysts for the oxygen reduction reaction. J. Am. Chem. Soc. 2012, 134, 9082-9085. [CrossRef] [PubMed]

143. Yang, Y.; Xu, L.; Li, W.; Fan, W.; Song, S.; Yang, J. Adsorption and degradation of sulfadiazine over nanoscale zero-valent iron encapsulated in three-dimensional graphene network through oxygen-driven heterogeneous Fenton-like reactions. Appl. Catal. B Environ. 2019, 259, 118057. [CrossRef]

144. Ghanbarlou, H.; Nasernejad, B.; Fini, M.N.; Simonsen, M.E.; Muff, J. Synthesis of an iron-graphene based particle electrode for pesticide removal in three-dimensional heterogeneous electro-Fenton water treatment system. Chem. Eng. J. 2020, 395, 125025. [CrossRef]

145. Shen, J.; Li, Y.; Zhu, Y.; Hu, Y.; Li, C. Aerosol synthesis of Graphene-Fe ${ }_{3} \mathrm{O}_{4}$ hollow hybrid microspheres for heterogeneous Fenton and electro-Fenton reaction. J. Environ. Chem. Eng. 2016, 4, 2469-2476. [CrossRef]

146. Mi, X.; Yang, M.; Xie, L.; Li, Y.; Sun, Y.; Zhan, S. RGO/MoS ${ }_{2} \mathrm{Ce}_{0.75} \mathrm{Zr}_{0.25} \mathrm{O}_{2}$ electro-Fenton cathode with higher matching and complementarity for efficient degradation of ciprofloxacin. Catal. Today 2020, 339, 371-378. [CrossRef]

147. Yang, Y.; Liu, Y.; Fang, X.; Miao, W.; Chen, X.; Sun, J.; Ni, B.J.; Mao, S. Heterogeneous Electro-Fenton catalysis with HKUST-1-derived Cu@C decorated in 3D graphene network. Chemosphere 2020, 243, 125423. [CrossRef]

148. Haider, M.R.; Jian, W.-L.; Han, J.-L.; Sharif, H.M.A.; Ding, Y.-C.; Chen, H.-Y.; Wang, A.-J. In-situ electrode fabrication from polyaniline derived $\mathrm{N}$-doped carbon nanofibers for metal-free electro-Fenton degradation of organic contaminants. Appl. Catal. B Environ. 2019, 256, 117774. [CrossRef]

149. Yu, T.; Breslin, C.B. Review-Two-dimensional titanium carbide MXenes and their emerging applications as electrochemical sensors. J. Electrochem. Soc. 2020, 167, 037514. [CrossRef] 
150. Zhou, S.; Yang, X.; Pei, W.; Liu, N.; Zhao, J. Heterostructures of MXenes and N-doped graphene as highly active bifunctional electrocatalysts. Nanoscale 2018, 10, 10876-10883. [CrossRef]

151. Zhang, Z.; Li, H.; Zou, G.; Fernandez, C.; Liu, B.; Zhang, Q.; Hu, J.; Peng, Q. Self-Reduction Synthesis of New MXene/Ag Composites with Unexpected Electrocatalytic Activity. ACS Sustain. Chem. Eng. 2016, 4, 6763-6771. [CrossRef]

152. Liu, H.; Tang, Y.; Zhao, W.; Ding, W.; Xu, J.; Liang, C.; Zhang, Z.; Lin, T.; Huang, F. Facile synthesis of nitrogen and halogen dual-doped porous graphene as an advanced performance anode for lithium-ion batteries. Adv. Mater. Interfaces 2018, 5, 1701261. [CrossRef]

153. Olanrele, S.O.; Lian, Z.; Si, C.; Chen, S.; Li, B. Tuning of interactions between cathode and lithium polysulfide in Li-S battery by rational halogenation. J. Energy Chem. 2020, 49, 147-152. [CrossRef]

154. Li, M.; Zhu, J.; Wang, M.; Fang, H.; Zhu, G.; Wang, Q. Exposure to graphene oxide at environmental concentrations induces thyroid endocrine disruption and lipid metabolic disturbance in Xenopus laevis. Chemosphere 2019, 236, 124834. [CrossRef]

(C) 2020 by the authors. Licensee MDPI, Basel, Switzerland. This article is an open access article distributed under the terms and conditions of the Creative Commons Attribution (CC BY) license (http://creativecommons.org/licenses/by/4.0/). 